\title{
Echinococcosis: a Challenge for Liver Sonography
}

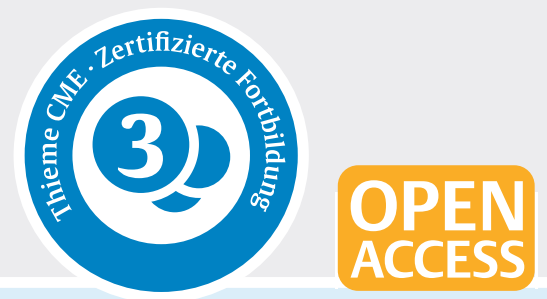

\section{(ㄷ) (1) $(9)$}

Authors

Wolfgang Kratzer, Henriette Weimer, Julian Schmidberger

Affiliation

Department of Internal Medicine I, Universitätsklinikum Ulm, Germany

Bibliography

Ultraschall in Med 2022; 43: 120-145

Published online: March 14, 2022

DOI $10.1055 / a-1694-5552$

ISSN $0172-4614$

(C) 2022. The Author(s).

This is an open access article published by Thieme under the terms of the Creative Commons Attribution-NonDerivative-NonCommercial License, permitting copying and reproduction so long as the original work is given appropriate credit. Contents may not be used for commecial purposes, or adapted, remixed, transformed or built upon. (https://creativecommons.org/licenses/by-nc-nd/4.0/)

Georg Thieme Verlag KG, Rüdigerstraße 14,

70469 Stuttgart, Germany

\section{ABSTRACT}

The sonographic findings in alveolar echinococcosis (AE) and cystic echinococcosis (CE) are complex and can pose significant differential diagnostic problems. They may present like complicated cysts or malignant tumors in the liver. We will discuss the diagnostic difficulties and pitfalls of these two diseases based on case histories.

\section{Introduction}

Due to the currently widespread availability of sonography, mostly benign masses of the liver are being discovered increasingly frequently as incidental findings. By far the most common masses found in the liver are focal hyposteatosis, simple liver cysts and hemangiomas. Detection of focal nodular hyperplasia (FNH) and liver adenomas is 10 to 100 times less common than simple cysts, hemangiomas or focal hyposteatosis [1]. Complex cysts and non-typical masses, especially during screening examinations or upper abdominal sonography due to other complaints, present investigators with the question of whether the lesion is an atypical benign lesion or a previously unknown primary malignant or metastatic lesion of a previously unknown underlying malignant disease [2].

The sonographic findings in fox tapeworm disease (alveolar echinococcosis, AE) and canine tapeworm disease (cystic echinococcosis, CE) are complex and can pose significant differential diagnostic problems. They may present as complex cysts or as malignant tumors in the liver. Based on case reports, we will discuss the diagnostic difficulties and pitfalls of these two diseases in the following article [3].

\section{Geographic Distribution and Development Cycles of these Diseases}

$\mathrm{AE}$ and $\mathrm{CE}$ are two completely different diseases [4]. Thus, the two diseases differ with respect to their development cycles and geographic distribution. As part of the reporting requirement under Section 7 (3) of the German Infection Protection Act (IfSG), 87 cases of CE and 41 cases of $A E$ were reported to the Robert Koch Institute in 2019. A high number of unrecognized cases and underreporting can be assumed, as data from the German National Echinococcosis Registry suggest. For $A E$, the data show a slightly increasing trend, while the number of cases for CE has stagnated at a stable level.

\section{Fox Tapeworm Disease (Echinococcus multilocularis)}

$\mathrm{AE}$ is a zoonosis transmissible by the larval stage of the cestode Echinococcus multilocularis (E. multilocularis) [5]. Germany is one of the world's high-risk regions. Most cases have been reported by the states of Baden-Württemberg and Bavaria ( $\triangleright$ Fig. 1, 2) [6, 7]. 


\section{Echinokokkose: eine Herausforderung für die Lebersonografie}

\section{() (1) $\circledast \oplus$}

\section{Autoren}

Wolfgang Kratzer, Henriette Weimer, Julian Schmidberger

Institut

Department of Internal Medicine I, Universitätsklinikum Ulm, Germany

Bibliografie

Ultraschall in Med 2022; 43: 120-145

Published online: 2022

DOI $10.1055 / a-1694-5552$

ISSN $0172-4614$

(C) 2022. The Author(s).

This is an open access article published by Thieme under the terms of the Creative Commons Attribution-NonDerivative-NonCommercial License, permitting copying and reproduction so long as the original work is given appropriate credit. Contents may not be used for commecial purposes, or adapted, remixed, transformed or built upon. (https://creativecommons.org/licenses/by-nc-nd/4.0/)

Georg Thieme Verlag KG, Rüdigerstraße 14,

70469 Stuttgart, Germany

\section{ZUSAMMENFASSUNG}

Die sonografischen Befunde bei Alveolärer Echinokokkose (AE) und Zystischer Echinokokkose (CE) sind komplex und können erhebliche differenzialdiagnostische Probleme aufwerfen. Sie können sich wie komplizierte Zysten oder wie bösartige Tumore in der Leber präsentieren. Wir werden die diagnostischen Schwierigkeiten und Fallstricke dieser beiden Erkrankungen anhand von Fallbeispielen diskutieren.

\section{Einleitung}

Aufgrund der inzwischen flächendeckenden Verfügbarkeit der Sonografie werden immer häufiger - als Zufallsbefund - meist benigne Raumforderungen der Leber entdeckt. Die mit Abstand am häufigsten in der Leber gefundenen Raumforderungen sind fokale Minderverfettungen bei Steatosis hepatis, einfache Leberzysten und Hämangiome. Der Nachweis von fokal nodulären Hyperplasien (FNH) und Leberadenomen ist 10- bis 100-mal seltener als einfache Zysten, Hämangiome oder fokale Minderverfettungen [1]. Komplizierte Zysten und nicht typische Raumforderungen stellen vor allem im Rahmen von Vorsorgeuntersuchungen oder Oberbauchsonografien aufgrund anderer Beschwerden die Untersucher vor die Frage, ob es sich um eine atypische benigne Läsion oder eine bisher nicht bekannte, primär maligne oder metastasensuspekte Läsion einer bisher nicht bekannten malignen Grunderkrankung handelt [2].

Die sonografischen Befunde bei der Fuchsbandwurm-Erkrankung (Alveoläre Echinokokkose, AE) und der Hundebandwurm-Erkrankung (Zystische Echinokokkose, CE) sind komplex und können erhebliche differenzialdiagnostische Probleme bereiten. Sie können sich wie komplizierte Zysten oder wie maligne Tumore in der Leber präsentieren. Anhand von Kasuistiken wollen wir im Folgenden auf die diagnostischen Schwierigkeiten und Fallstricke dieser beiden Erkrankungen eingehen [3].

\section{Geografisches Vorkommen und Entwicklungszyklen der beiden Erkrankungen}

Bei der AE und CE handelt es sich um 2 völlig unterschiedliche Erkrankungen [4]. So unterscheiden sich die beiden Erkrankungen bezüglich ihrer Entwicklungszyklen und des geografischen Vorkommens. Dem Robert Koch-Institut wurden im Rahmen der Meldepflicht nach § 7 Abs. 3 IfSG im Jahr 201987 Fälle mit CE und 41 Fälle mit AE gemeldet. Von einer hohen Dunkelziffer und Untererfassung ist auszugehen, wie Daten des Nationalen- Echinokokkose-Registers nahelegen. Für die AE zeigen die Daten einen leicht ansteigenden Trend, während die Fallzahlen der CE auf einem stabilen Niveau stagnieren.

\section{Fuchsbandwurm (Echinococcus multilocularis)}

Die AE ist eine durch das Larvenstadium des Cestoden Echinococcus multilocularis (E. multilocularis) übertragbare Zoonose [5]. Weltweit zählt Deutschland zu den Hochrisikogebieten. Die meisten Fälle werden aus Baden-Württemberg und Bayern berichtet $(\triangleright$ Abb. 1, 2) $[6,7]$. 


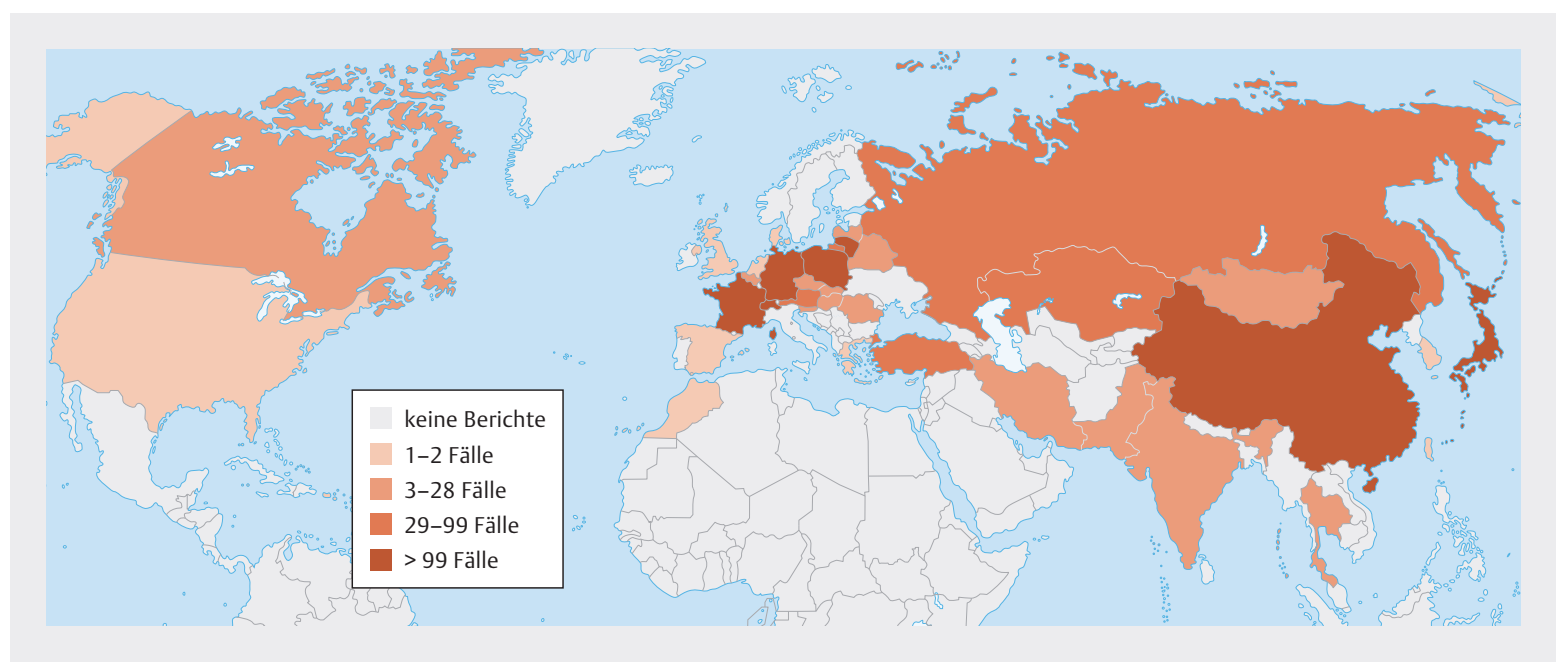

- Fig. 1 Global distribution of alveolar echinococcosis according to published literature 2001-2018.

- Abb. 1 Weltweite Verteilung der Alveolären Echinokokkose beim Menschen gemäß der veröffentlichten Literatur 2001-2018.

The adult cestode E. multilocularis produces infectious worm eggs in the gastrointestinal tract of its final host (mostly foxes), which are excreted as mature worm eggs in the feces of this host and contain infectious oncospheres (first larva of the tapeworm) [8]. In Europe, the red fox (Vulpes vulpes) is the most common final host [9]. As part of the sylvatic cycle, natural intermediate hosts, generally mice, ingest the infectious worm eggs. The egg capsule dissolves in the gastrointestinal tract of the mice, releasing the so-called oncospheres (hexacanthene larvae). Intrinsic activation and penetration of the intestinal wall is usually followed by infestation of the liver of the intermediate host [10]. There, the oncospheres develop into the metacestode (second larva of the tapeworm), which in turn gives rise to fertile protoscolices, which then develop into adult worms (cestodes). In the course of this process, the mouse becomes ill (natural intermediate host). If this diseased mouse is eaten by a fox, the life cycle of E. multilocularis is complete [10]. However, accidental intermediate hosts such as humans can also be infected by $E$. multilocularis by coincidental oral ingestion of infectious worm eggs. The time between infection and diagnosis can range from 10 to 15 years, although the exact time of infection is usually impossible to determine. Due to its untreated 90 percent mortality within 10-15 years of diagnosis, AE is one of the most dangerous parasitoses in Central Europe [11]. The individual development steps within the accidental intermediate host are similar to those in the natural intermediate host. However, there is no further transmission of the parasite to fertile fox tapeworm larvae (protoscolices) in the liver of the accidental intermediate host ( Fig. 3).

\section{Alveolar Echinococcosis (Fox Tapeworm Disease)}

Patients are typically asymptomatic in the initial stage of fox tapeworm disease. First symptoms may include nonspecific upper abdominal pain, fatigue and jaundice; Generally these symptoms occur with long-standing disease, since the incubation period can take 5-15 years [4]. Complications such as biliary obstruction, portal hypertension, and bleeding esophageal varices have been described in advanced disease stages and are attributed to the invasive growth of $E$. multilocularis lesions in the liver $[12,13]$. The following case reports on a patient from a high-risk area in Baden-Württemberg who had "re-imported" the disease. All initially suspected were not confirmed.

\section{EXAMPLE CASE 1}

A 35-year-old patient had emigrated from southern Germany to the Caribbean several years previously. For 3 months he complained there of a slowly increasing deterioration of his general state of health. Due to progressive deterioration of his health, the patient decided to return to Germany. Based in his prior medical history, there were no known significant previous diseases. At the time of initial presentation in our clinic, the patient's physical examination was unremarkable. Normal EKG, body mass index was 21. Laboratory chemistry revealed an elevated $\gamma$-glutamyl transferase (GGT) of $146 \mathrm{U} / \mathrm{L}$ 


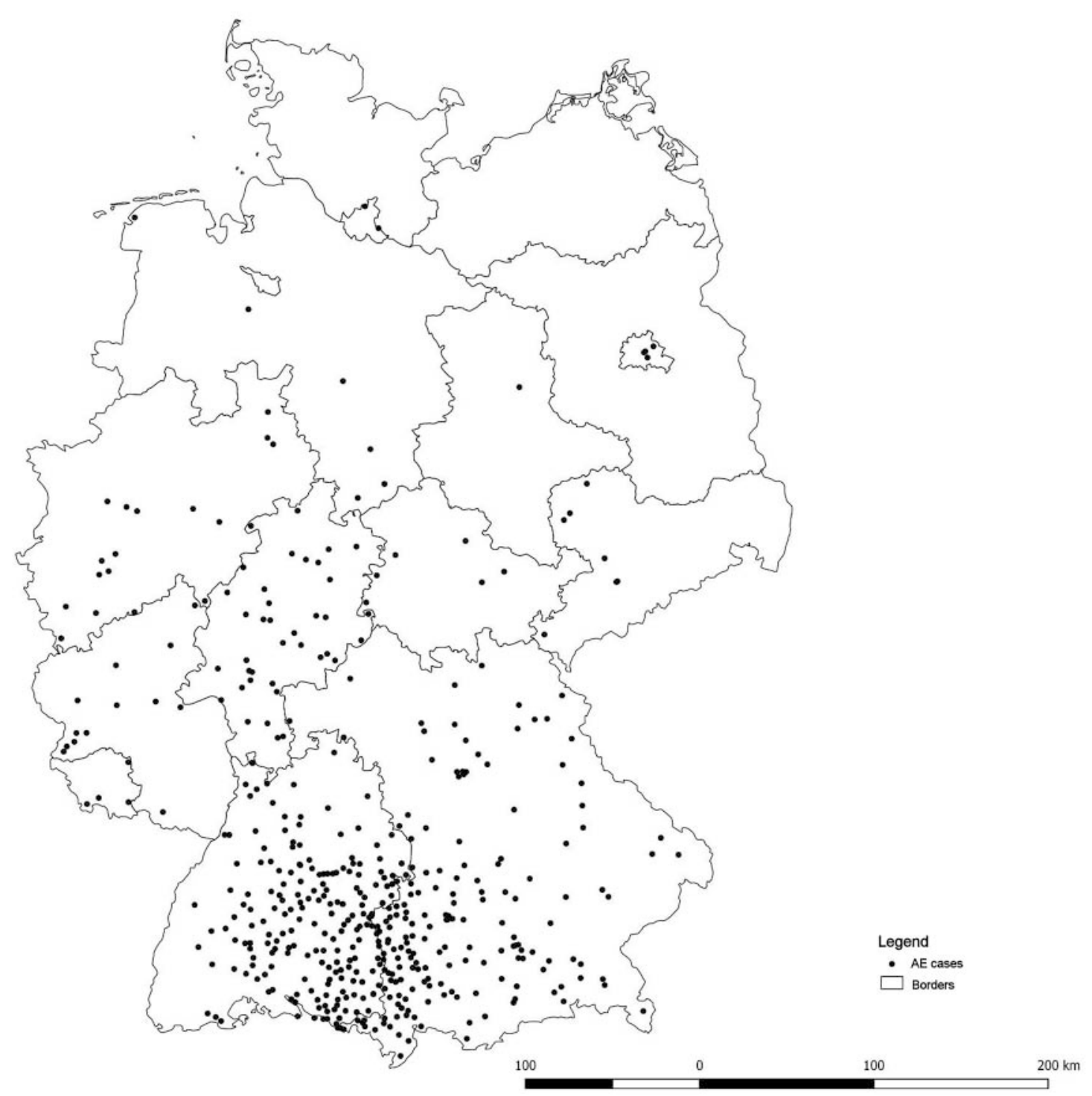

- Fig. 2 Geographic distribution of human alveolar echinococcosis in Germany, 1992-2018.

- Abb.2 Geografische Verteilung der humanen Alveolären Echinokokkose in Deutschland, 1992-2018.

Die adulte Cestode E. multilocularis produziert im GastroIntestinaltrakt seines Endwirts (meist Füchse) infektiöse Wurmeier, welche als reife Wurmeier über den Kot des Endwirts ausgeschieden werden und infektiöse Onkosphären (erste Larve des Bandwurmes) enthalten [8]. In Europa gilt dabei der Rotfuchs (Vulpes vulpes) als häufigster Endwirt [9]. Im Rahmen des sylvatischen Zyklus nehmen natürliche Zwischenwirte, meist Mäuse, die infektiösen Wurmeier auf. Im Magen-Darmtrakt der Mäuse löst sich die Eikapsel auf, wodurch die sogenannten Onkosphären (Hexacanthenlarven) frei werden. Nach intrinsischer Aktivierung und Penetration der Darmwand erfolgt meist ein Befall der Leber des Zwischenwirts [10]. Dort entwickeln sich die Onkosphären zur Metaces- tode (zweite Larve des Bandwurmes), aus welcher dann wiederum fertile Protoscolices entstehen. Diese entwickeln sich zu adulten Würmern (Cestoden). Im Rahmen dieses Prozesses erkrankt die Maus (als natürlicher Zwischenwirt). Wenn diese erkrankte Maus von einem Fuchs gefressen wird, ist der Lebenszyklus von $E$. multilocularis komplettiert [10]. Durch akzidentielle orale Ingestion infektiöser Wurmeier können jedoch auch Fehlzwischenwirte wie der Mensch durch E. multilocularis befallen werden. Die Zeit zwischen Infektion und Diagnose kann zwischen 10 und 15 Jahren betragen, wobei der genaue Infektionszeitpunkt meist nicht bestimmbar ist. Aufgrund ihrer unbehandelten 90-prozentigen Letalität binnen 10-15 Jahren nach Diagnosestellung gilt die AE 


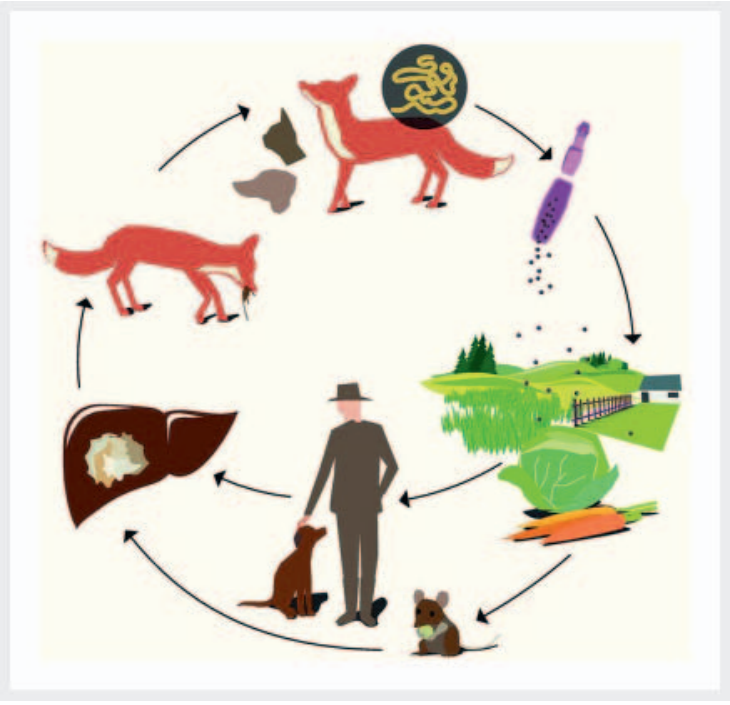

- Fig. 3 Life and developmental cycle of Echinococcus multilocularis [4].

- Abb. 3 Lebens- und Entwicklungszyklus des Echinococcus multilocularis [4].

(normal $<60 \mathrm{U} / \mathrm{L}$ ). C-reactive protein (CRP) was also elevated at $16.5 \mathrm{mg} / \mathrm{L}$ (normal $<5 \mathrm{mg} / \mathrm{L}$ ). Otherwise, there were no other abnormalities in the extensive laboratory diagnostics. Ultrasound revealed a large mass which occupied the entire right hepatic lobe. The cystoid mass had an irregular hyperechoic sturdy wall and hypoechoic central necrosis ( $\bullet$ Fig. 4A). After appropriate preparations, the patient underwent surgery with a curative approach. A hemihepatectomy of the right hepatic lobe was performed as part of the surgery.

The above case provides a typical picture of $A E$ with a pseudocystic pattern. The pseudocystic pattern has irregular anechoic wall thickening in the marginal area and centrally a hypoechoic or partially anechoic necrotic area. At most, a differential diagnosis can be differentiated from a large liver abscess ( $>$ Fig. 4B). By including these clinical symptoms, this form of presentation of the AE B-scan is easy to diagnose using sonography, because a liver abscess could largely be ruled out due to the persistent absence of fever in the patient's history $(\triangleright$ Fig. 4A, B). In this case the diagnosis was made based exclusively on ultrasound.

\section{Note}

Fox tapeworm disease has no specific clinical symptoms; symptoms often only appear in later stages. Initial symptoms may include nonspecific upper abdominal pain, fatigue and cholestatic jaundice. The incubation period can take five to fifteen years.
Until 2002, only one MRI graphical classification was available for the various presentation patterns of $\mathrm{AE}$ [14]. Kodama classification distinguishes five patterns. Due to the physical principle of action, the manifestation forms of AE described in the MRI classification differ considerably from those in ultrasound [15]. Typical sonographic patterns, especially the so-called storm and hail pattern, were described sonographically early on [16]. An ultrasound classification was first published in 2016, likewise consisting of five patterns ( $\triangleright$ Fig. 5) [17]. The storm and hail pattern is the most common found in Germany, accounting for over $50 \%$ of cases, and is pathognomonic for the disease ( $\triangleright$ Fig. 6). There are few other differential diagnoses in B-scan sonography, so that a sonomorphological diagnosis is possible with typical presentation. Most commonly, this manifestation form is mistaken for cholangiocellular carcinoma [2].

Distribution of sonographic patterns by frequency (\%):

- Storm and hail pattern: $54.1 \%$

- Pseudocystic pattern: $13.5 \%$

- Ossification pattern: $13.0 \%$

- Hemangioma-like pattern: $8.1 \%$

- Metastatic pattern: $6.5 \%$

- Non-classifiable: $4.8 \%$

\section{Note}

Just as with MRI classification, sonographic classification of alveolar echinococcosis (fox tapeworm disease) can distinguish among five forms of presentation. The so-called storm and hail pattern is the most common in Germany.

Image morphological suspicion of AE should be confirmed serologically according to WHO-IWGE recommendations. Positive serology without a corresponding imaging correlate is not considered a disease at this time. The sensitivity of the echinococcosis screening test with hydatid fluid from $E$. granulosus is reported here to be 94-97\% for AE, and the Em total larvae ELISA is reported to have a sensitivity of approximately $95 \%$. For the confirmation test (Em10, Em18, EmII/ 3 or Em2) with purified or recombinant antigens of the germinal or laminar layer of $E$. multilocularis, the sensitivity is given as $90-100 \%$ and specificity as $95-100 \%[18,19]$.

\section{EXAMPLE CASE 2}

A 68-year-old female patient in good general health was referred by her general practitioner to an endocrinologist for further treatment and diagnostics in the presence of known arterial hypertension, type 2 diabetes, diabetic nephropathy and suspected hypothyroidism. The internal medicine/endocrinology workup revealed satisfactory kidney and blood glucose levels. Due to known nephropathy, ultrasound 

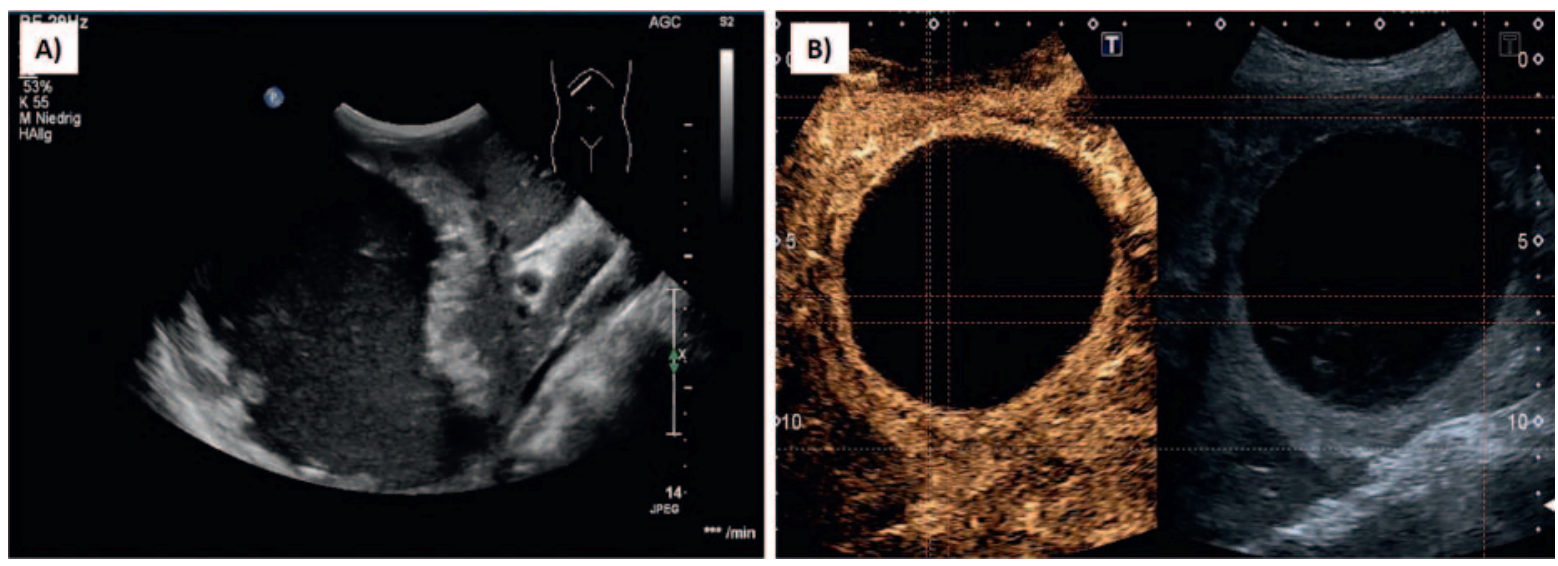

- Fig. 4 A The sonogram shows a hypoechoic mass of the right hepatic lobe with irregular hyperechoic margin and central necrosis. The image corresponds to a so-called pseudocystic pattern and is typical for alveolar echinococcosis. B For comparison: Abscess in contrast-enhanced sonography.

- Abb. 4 A Das Sonogramm zeigt eine echoarme Raumforderung des rechten Leberlappens mit irregulärem echoreichem Randsaum und zentraler Nekrose. Das Bild entspricht einem sogenannten pseudozystischen Muster und ist typisch für eine Alveoläre Echinokokkose. B Zum Vergleich: Abszess in der kontrastverstärkten Sonografie.

als eine der gefährlichsten Parasitosen Mitteleuropas [11]. Die einzelnen Entwicklungsschritte innerhalb des Fehlzwischenwirts gleichen denen im natürlichen Zwischenwirt. Es erfolgt jedoch keine weitere Transmission des Parasiten zu fertilen Fuchsbandwurm-Kopfanlagen (Protoscolices) in der Leber des Fehlzwischenwirts ( $\triangleright$ Abb. 3).

\section{Alveoläre Echinokokkose (Fuchsbandwurm-Erkrankung)}

In der Anfangsphase der Fuchsbandwurminfektion sind die Patienten typischerweise asymptomatisch. Zu den ersten Symptomen können unspezifische Oberbauchschmerzen, Abgeschlagenheit und Gelbsucht gehören. Meist treten diese Symptome bei lang bestehender Erkrankung auf. Die Inkubationszeit kann 5-15 Jahre betragen [4]. Komplikationen wie biliäre Obstruktion, portale Hypertension und blutende Ösophagusvarizen wurden in fortgeschrittenen Krankheitsstadien beschrieben und werden auf das invasive Wachstum von $E$. multilocularis-Läsionen in der Leber zurückgeführt $[12,13]$. Der nachfolgende Fall berichtet über einen Patienten aus einem Hochrisikogebiet aus Baden-Württemberg, der die Erkrankung „reimportiert“ hatte. Alle seltenen Tropenerkrankungen, welche zunächst vermutet wurden, bestätigten sich nicht.

\section{FALLBEISPIEL 1}

Ein 35-jähriger Patient war vor einigen Jahren aus Süddeutschland in die Karibik ausgewandert. Seit 3 Monaten klagte er dort über eine langsam zunehmende Verschlechterung seines Allgemeinzustandes
(AZ). Wegen fortschreitender AZ-Verschlechterung entschloss sich der Patient zur Rückkehr nach Deutschland. Aus der Vorgeschichte des Patienten waren keine wesentlichen Vorerkrankungen bekannt. Die körperliche Untersuchung des Patienten war zum Zeitpunkt der ersten Vorstellung in unserer Klinik unauffällig. Unauffälliges EKG, der Body-MassIndex war $21 \mathrm{~kg} / \mathrm{m}^{2}$. Laborchemisch fiel eine erhöhte Y-Glutamyl-Transferase (GGT) mit 146 U/L (Norm $<60 \mathrm{U} / \mathrm{L}$ ) auf. Das C-reaktive Protein (CRP) war mit $16,5 \mathrm{mg} / \mathrm{L}$ (Norm < $5 \mathrm{mg} / \mathrm{L}$ ) ebenfalls erhöht. Ansonsten ergaben sich keine weiteren Auffälligkeiten in der umfangreichen Labordiagnostik. Sonografisch konnte eine große Raumforderung, welche den gesamten rechten Leberlappen einnahm, dargestellt werden. Die zystoide Raumforderung hatte eine irreguläre echoreiche, kräftige Wand und eine echoarme zentrale Nekrose ( $\triangleright$ Abb. 4A). Nach entsprechenden Vorbereitungen wurden der Patient mit einem kurativen Ansatz operiert. Im Rahmen einer operativen Therapie erfolgte eine Hemihepatektomie des rechten Leberlappens.

Der oben genannte Fall zeigt ein typisches Bild einer AE mit einem pseudozystischen Muster. Das pseudozystische Muster weist im Randbereich eine irreguläre echoreiche Wandverdickung und zentral ein echoarmes, zum Teil echofreies Nekrose-Areal auf. Differenzialdiagnostisch ist allenfalls von einem großen Leberabszess zu differenzieren ( $\triangleright$ Abb. 4B). Unter Einbeziehung der Klinik ist diese Präsentationsform der AE B-Bild-sonografisch gut zu diagnostizieren, denn der differenzialdiagnostisch in Betracht kommende Leberabszess konnte aufgrund der 

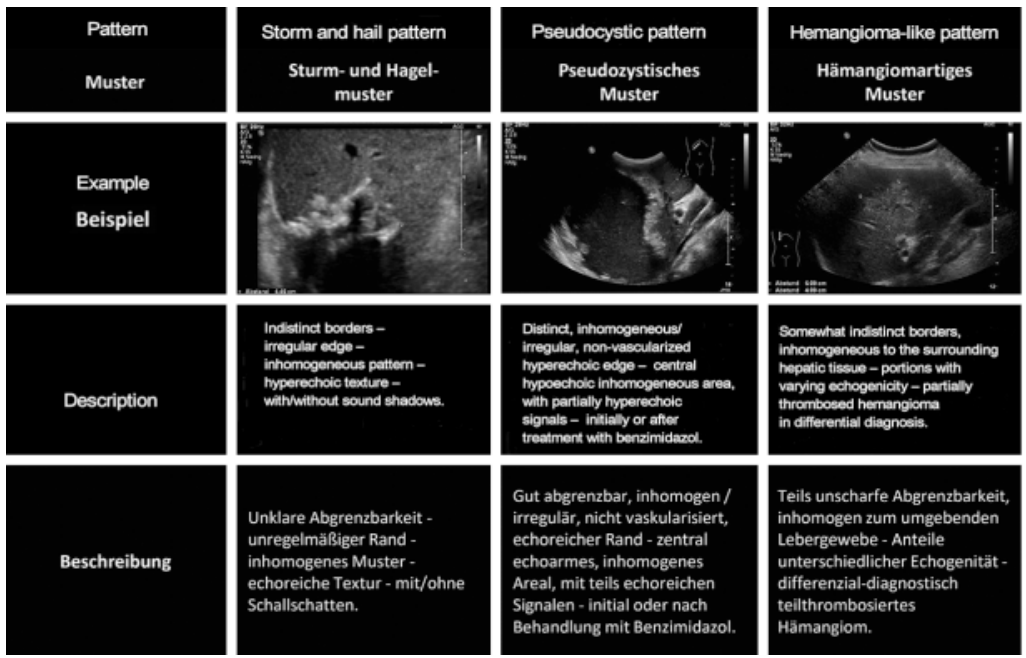

Gut abgrenzbar, inhomogen / irregulär, nicht vaskularisiert, echoreicher Rand - zentral echoarmes, inhomogenes
Areal, mit teils echoreichen Areal, mit teils echoreichen Signalen - initial oder nach
Behandlung mit Benzimidazol.
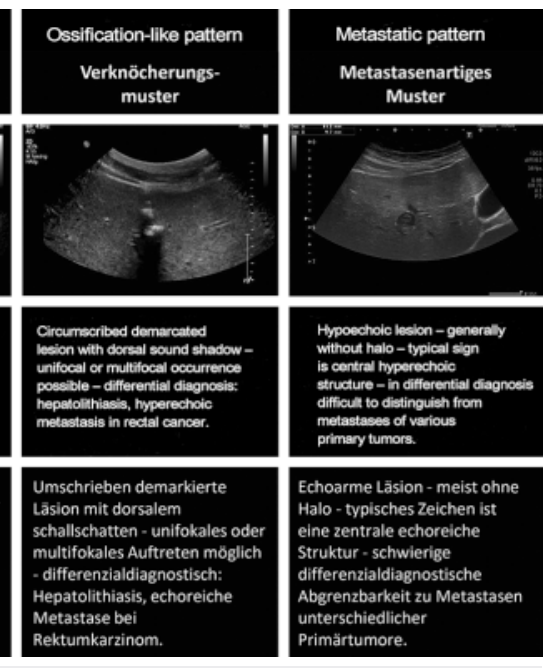

- Fig. 5 Echinococcus multilocularis Ulm Classification - Ultrasound (EMUC-US) for image morphological characterization of alveolar echinococcosis.

- Abb. 5 Echinococcus multilocularis Ulm Classification - Ultrasound (EMUC-US) zur bildmorphologischen Charakterisierung der alveolären Echinokokkose.

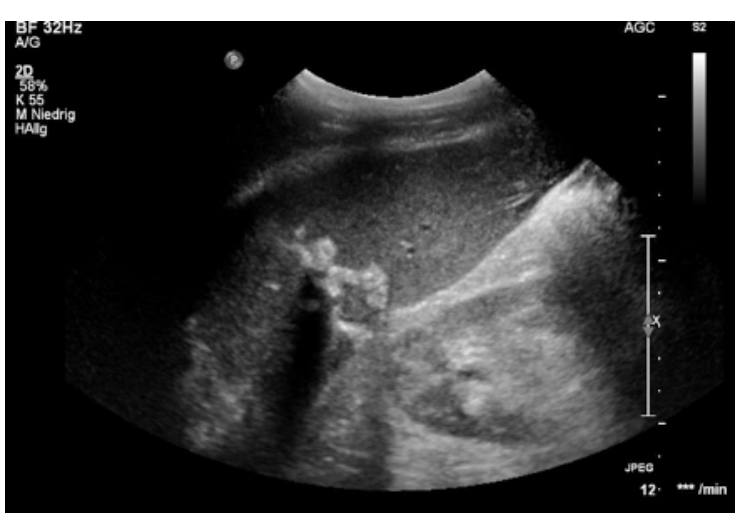

- Fig. 6 Typical storm and hail pattern according to the Echinococcus multilocularis Ulm Classification - Ultrasound (EMUC-US). The storm and hail pattern is characterized by unclear delineation, an irregular edge structure, an inhomogeneous pattern with hyperechoic structure with and without sound shadows.

- Abb. 6 Typisches Sturm- und Hagelmuster entsprechend der Echinococcus multilocularis Ulm Classifikation - Ultrasound (EMUC-US). Das Sturm- und Hagelmuster ist charakterisiert durch eine unklare Abgrenzbarkeit, eine unregelmäßige Randstruktur, ein inhomogenes Muster mit echoreicher Struktur mit und ohne Schallschatten.

of the upper abdomen was performed. Two suspicious metastatic lesions were evident in liver segment IVa and IVb/II ( $\triangleright$ Fig. 7A, B). Based on these findings, CT was performed which confirmed the suspicions. Mammography was unremarkable. Further gynecological observations were likewise normal. Determination of the tumor markers CEA, alphafetoprotein, Ca-125, and Ca-19-9 was unremarkable. For further clarification of the masses suspected of metastasis by $\mathrm{CT}$, an outpatient gastroenterological evaluation was carried out using gastroscopy, colonoscopy and proctoscopy, which only revealed slight chronic gastritis. Since extensive tumor screening was unsuccessful, the patient was referred to the university hospital for further clarification.

Further evaluation by contrast-enhanced ultrasoundrevealed arterial rim enhancement in both masses during the arterial phase and no contrast enhancement during the portal venous and late phases up to four minutes post-injection ( $\boldsymbol{F}$ Fig. $\mathbf{8 A}$ ). Based on these findings, the masses were further classified as metastatic and ultrasound-guided puncture was recommended. Due to suspicion of cancer of unknown primary origin (CUP), the mass in liver segment VII was punctured three times with a needle with $18 \mathrm{G}$ thickness corresponding to $1.2 \mathrm{~mm}$ ( $\triangleright$ Fig. 8B).

Histology revealed a punch cylinder with moderate steatosis and a tiny granuloma with no evidence of malignancy. A new puncture was performed due to a finding of suspected sarcoidosis. Immunohistological processing of the biopsies revealed an Echinococcus multilocularis infection ( $\bullet$ Fig. 9). A PET CT also confirmed two weakly positive focal findings with mildly increased metabolic activity compared to the liver level ( $\triangleright$ Fig. 10A, B).

The case described above impressively shows the considerable diagnostic difficulties posed by the metastatic pattern of AE. Previously unpublished data show that the metastatic pattern in contrast-enhanced ultrasound 

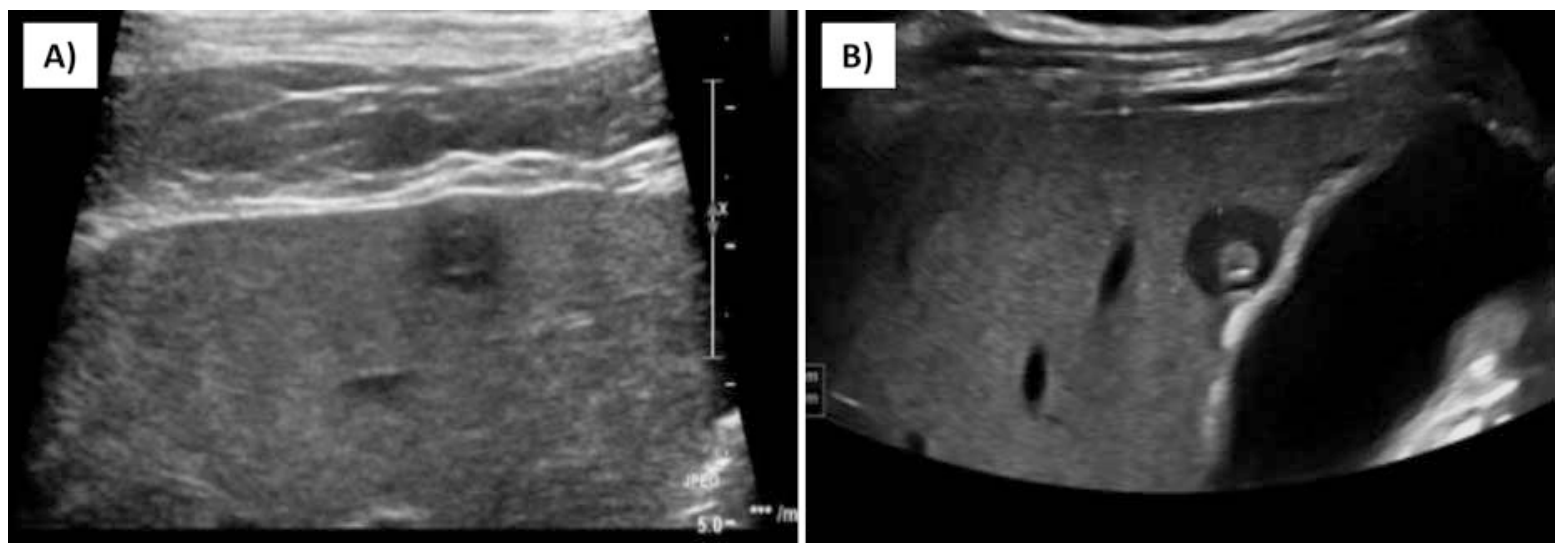

- Fig.7 A Hypoechoic mass in liver segment IVb/II; B hypoechoic mass in a metastatic pattern of Echinococcus multilocularis Ulm Classification - Ultrasound (EMUC-US) with central hyperechoic scar corresponding to a laminar body of Echinococcus multilocularis in segment IVa. Unpublished data show that hyperechoic scars at presentation appear to grow over time.

- Abb.7 A Echoarme Raumforderung im Lebersegment IVb/II. B Echoarme Raumforderung bei metasasenartigem Muster der Echinococcus multilocularis Ulm Klassifikation - Ultraschall (EMUC-US) mit zentral echoreicher Narbe entsprechend einem Laminarkörper des Echinococcus multilocularis in Segment IVa. Nicht publizierte Daten zeigen, dass im zeitlichen Verlauf die echoreichen Narben bei der Präsentation über die Zeit zuzunehmen scheinen.

anamnestisch fortwährenden Fieberfreiheit weitestgehend ausgeschlossen werden ( $\triangleright$ Abb.4A, B). In diesem Fall wurde die Diagnose ausschließlich sonografisch gestellt.

\section{Merke}

Die Fuchsbandwurm-Erkrankung hat keine spezifische klinische Symptomatik; häufig treten Symptome erst in späteren Stadien auf. Zu den ersten Symptomen können unspezifische Oberbauchschmerzen, Abgeschlagenheit und cholestatische Gelbsucht gehören. Die Inkubationszeit kann 5 bis 15 Jahre betragen.

Bis 2002 stand für die verschiedenen Präsentationsmuster der AE lediglich eine MRT-grafische Klassifikation zur Verfügung [14]. Die Klassifikation nach Kodama unterscheidet dabei 5 Muster. Aufgrund des physikalischen Wirkprinzips unterscheiden sich die in der MRT-Klassifikation beschrieben Manifestationsformen der AE erheblich von denen im Ultraschall [15]. Typische sonografische Muster, insbesondere das sogenannte Sturm- und Hagelmuster, wurden sonografisch bereits früh beschrieben [16]. Eine Ultraschallklassifikation wurde erstmals 2016, ebenfalls aus 5 Mustern bestehend, publiziert ( $\mathbf{A b b} \mathbf{5}$ ) [17]. Das Sturm- und Hagelmuster ist mit über $50 \%$ der Fälle das häufigste in Deutschland gefundene Muster und pathognomonisch für die Erkrankung ( $\triangleright$ Abb.6). BBild-sonografisch gibt es hierzu wenige andere Differenzialdiagnosen, sodass bei typischer Präsentation eine sono-morphologische Diagnose möglich ist. Am häufigsten wird diese Manifestationsform mit einem cholangiozellulären Karzinom verwechselt [2].
Verteilung sonografischer Muster nach Häufigkeit (\%):

- Sturm- und Hagelmuster: $54,1 \%$

- Pseudozystisches Muster: 13,5\%

- Verknöcherungsmuster: 13,0\%

- hämangiomartiges Muster: 8,1\%

- metastasenartiges Muster: 6,5\%

- Nicht klassifizierbar: 4,8\%

Merke

Wie für die MRT-Klassifikation kann auch bei der sonografischen Klassifikation der Alveolären Echinokokkose (Fuchsbandwurm-Erkrankung) zwischen 5 Präsentationsformen unterschieden werden. Das sogenannte Sturm- und Hagelmuster ist die häufigste Präsentationsform in Deutschland.

Ein bildmorphologischer Verdacht auf eine AE sollte entsprechend den Empfehlungen der WHO-IWGE serologisch bestätigt werden. Eine positive Serologie ohne ein entsprechendes bildgebendes Korrelat gilt nach derzeitigem Stand nicht als Erkrankung. Die Sensitivität des Echinokokkose-Suchtests mit Hydatiden-Flüssigkeit von E. granulosus wird hierbei mit 94-97\% für die AE angegeben, der Em-Gesamtlarven-ELISA mit einer Sensitivität von ca. $95 \%$. Für den Bestätigungstest (Em10, Em18, EmIl/3 bzw. Em2) mit aufgereinigten bzw. rekombinanten Antigenen der Germinal- bzw. Laminarschicht von E. multilocularis wird die Sensitivität mit 90-100\% und die Spezifität mit 95-100\% angegeben [18, 19]. 

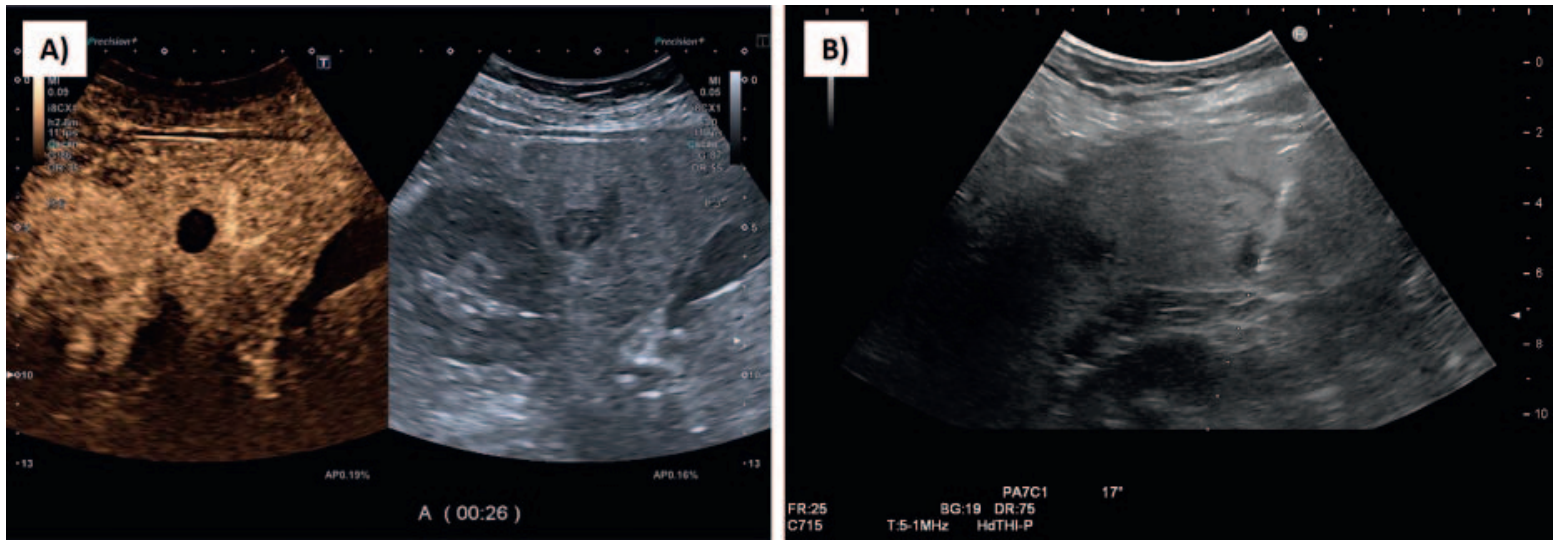

- Fig. 8 A Contrast-enhanced ultrasound (CEUS) of ambiguous mass suspicious of metastasis. B Ultrasound-guided puncture of a mass suspicious of metastasis in liver segment VII.

- Abb.8 A Kontrastverstärkte Sonografie (CEUS) bei metastasensuspekter unklarer Raumforderung. B Sonografische Punktion einer metastasensuspekten Raumforderung im Lebersegment VII.

(CEUS) in the arterial phase demonstrates marked rim enhancement that remains detectable into the late phase. Based on these data, AE should be considered in patients with ambiguous incidental metastasis-like masses without corresponding clinical symptoms. A small central hyperechoic scar is often found in the metastatic pattern, but this may be absent. In most cases, the metastatic pattern is found during a routine clinical examination or as part of the workup for other medical conditions ( $\triangleright$ Fig. 11A, B). In addition to the metastatic-like pattern, a hemangioma-like pattern represents the most difficult form with respect to differential diagnosis ( $>$ Fig. 12).

Again, the distinction between a true hemangioma and a hemangioma-like pattern in $\mathrm{AE}$ can only be made using contrast-enhanced ultrasound ( $\triangleright$ Fig. 13A). The hemangioma-like pattern in alveolar echinococcosis may demonstrate early arterial rim enhancement. The typical contrast behavior of hemangiomas includes arterial peripheral nodular contrast enhancement and centripetal contrast flooding with complete or incomplete iris diaphragm phenomenon, as well as hyperechogenic visualization in the late phase compared with the liver parenchyma, which is less echoic [20] ( $\triangleright$ Fig. 13B-D). These phenomena, detectable in "true hemangiomas", are not found in the hemangioma-like pattern of $\mathrm{AE}$ ( Fig. 14A-D).

\section{Note}

Contrast-enhanced ultrasound can be used to differentiate between "true" hemangiomas and the hemangioma-like pattern seen in alveolar echinococcosis. The typical nodular rim enhancement and subsequent complete or incomplete iris diaphragm phenomenon are not found in the hemangioma-like pattern of alveolar echinococcosis. In the arterial phase, rim en- hancement is found instead. Otherwise, the mass remains anechoic throughout the contrast phase.

The so-called ossification pattern could be detected in approximately $13 \%$ of the cases recorded in the German National Fox Tapeworm Register ( $\triangleright$ Fig. 15A). It can be assumed that this is an encapsulated and no longer infectious calcification structure. The previous results of the few available PET CT studies failed to demonstrate activity with this form of presentation [15]. Differential diagnosis includes hepatolithiasis or hyperechoic metastasis of rectal cancer ( $\triangleright$ Fig. 15B, C). The cases described show the considerable differences in the forms of presentation of AE. In an impressive case series Stojkovic et al. demonstrated the problem of over- and under-treatment of $A E$ [3]. In principle, histological clarification should be sought if the sonographic findings are unclear. When clarifying a hemangioma-like pattern, contrast-enhanced ultrasound should be performed beforehand to reliably rule out a "true hemangioma", and if necessary, further sectional imaging by magnetic resonance imaging (MRI) should be undertaken. The involvement of a reference pathologist is recommended in case of ambiguous histological findings ( $\triangleright$ Fig. 9).

In $A E$, there is always an indication for therapy in the case of infiltrative growth. Treatment options include drug therapy and surgery. Approximately one-third of patients are diagnosed at a stage that is primarily operable locally. Only surgical resection of the affected portions of the liver with a $1-2 \mathrm{~cm}$ safety margin offers a chance of cure [4]. Benzimidazole drug therapy is indicated in all patients and is sometimes required for life. Albendazole $(A B Z)$ is given at a dose of $10-15 \mathrm{mg} / \mathrm{kgKG} / \mathrm{d}$ in two divided doses and should be taken with a high-fat meal. The only available alternative drug is mebendazole, which 


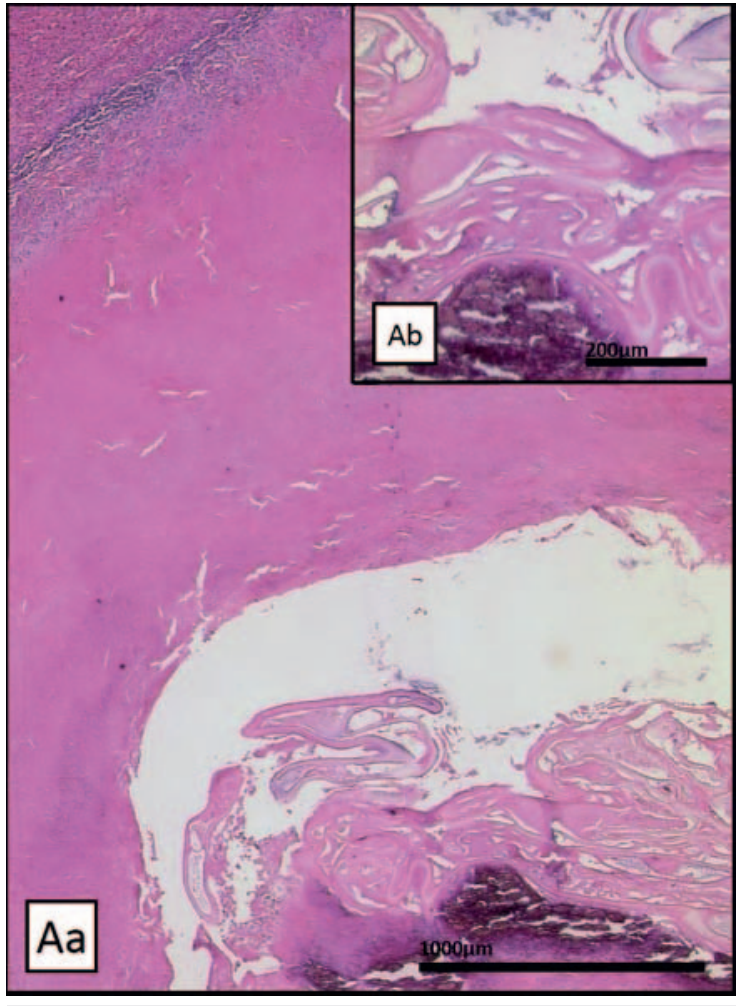

- Fig. 9 A Overview of a larval stage lesion of E. multilocularis in a human liver showing typical extensive necrosis, weak eosinophilic laminar body and central calcifications, and typical rim with interspersed lymphocytes. In magnification, the amorphous, partially calcified laminar body. Source: Institut für Pathologie der Universitätsklinik und der Medizinischen Fakultät der Universität Ulm, Prof. Dr. Thomas FE Barth.

- Abb.9 A Übersicht einer Läsion des Larvenstadiums von E. multilocularis in der humanen Leber mit typischen ausgedehnten Nekrosen, schwach eosinophilem Laminarkörper und zentralen Verkalkungen sowie typischem Randsaum mit eingestreuten Lymphozyten. In der Vergrößerung der amorphe, teils verkalkte Laminarkörper. Quelle: Institut für Pathologie der Universitätsklinik und der Medizinischen Fakultät der Universität Ulm, Prof. Dr. Thomas FE Barth.

\section{FALLBEISPIEL 2}

Eine 68-jährige beschwerdefreie Patientin in gutem Allgemeinzustand wurde bei bekannter arterieller Hypertonie, Typ-2-Diabetes, diabetischer Nephropathie und bei V.a. Hypothyreose vom Hausarzt an einen endokrinologischen Fachkollegen zur weiteren Mitbehandlung und Diagnostik überwiesen. Die internistisch/endokrinologische Abklärung ergab zufriedenstellende Nierenund Blutzuckerwerte. Bei bekannter Nephropathie erfolgte die Durchführung einer Oberbauchsonografie. Hier zeigten sich im Lebersegment IVa und IVb/II 2 echoarme metastasensuspekte Raumforderungen ( $\vee$ Abb. 7A, B). Aufgrund dieses Befundes erfolgte die Durchführung einer Computertomografie, welche den abklärungsbedürftigen Befund bestätigte. Eine Mammografie blieb ohne Befund. Die weitere gynäkologische Abklärung war ebenfalls unauffällig. Die Bestimmung der Tumormarker CEA, Alphafetoprotein, Ca-125 und Ca-19-9 waren unauffällig. Zur weiteren Abklärung der CT-grafisch metastasenverdächtigen Raumforderungen erfolgte danach eine ambulante gastroenterologische Abklärung mittels Gastroskopie, Koloskopie und Proktoskopie, welche lediglich eine leichte chronische Gastritis ergaben. Da die umfangreiche Tumorsuche erfolglos blieb, wurde die Patientin zur weiteren Abklärung an die Uniklinik überwiesen.

Hierbei zeigte sich im Rahmen der weiteren Abklärung mittels kontrastverstärkter Sonografie in der arteriellen Phase bei beiden Raumforderungen ein arterielles Rim-Enhancement und während der portalvenösen und Spätphase bis 4 Minuten post injectionem keine Kontrastmittelaufnahme ( $\vee$ Abb. 8A). Aufgrund dieses Befundes wurden die Raumforderungen weiter als metastasensuspekt eingestuft und eine sonografisch gesteuerte Punktion empfohlen. Bei Verdacht auf Cancer of Unknown Primary (CUP) wurde die Raumforderung im Lebersegment VII 3-mal mit einer Punktionsnadel der Nadeldicke 18G entsprechend 1,2 mm punktiert ( $\mathrm{Abb}$. 8B).

Die Histologie ergab einen Stanzzylinder mit mäßiger Verfettung und einem winzigen Granulom ohne Hinweise für Malignität. Aufgrund dieses Befundes bei V. a. Sarkoidose erfolgte eine erneute Punktion. Die immunhistologische Aufarbeitung der Biopsate ergab den Befund einer Echinococcus-multilocularisInfektion ( $\triangleright$ Abb. 9). Ein durchgeführtes PET-CT bestätigte ebenfalls 2 schwach positive Fokalbefunde mit im Vergleich zum Leberniveau gering vermehrter Stoffwechselaktivität ( $\triangleright$ Abb. 10A, B).

Der oben geschilderte Fall zeigt eindrucksvoll, welche erheblichen diagnostischen Schwierigkeiten das metastasenartige Muster der AE bereiten kann. Bisher nicht publizierte Daten zeigen, dass das metastasenartige Muster in der kontrastverstärkten Sonografie (CEUS) in der arteriellen Phase ein deutliches Rim-Enhancement zeigt, welches bis in die Spätphase nachweisbar bleibt. Schlussfolgernd aus diesen Daten sollte bei Patienten mit unklaren, zufälligen, metastasenartigen Raumforderungen ohne entsprechende Klinik an eine AE gedacht werden. Häufig findet man beim metastasenartigen Muster eine kleine, zentrale, echoreiche Narbe, welche jedoch auch fehlen kann. Meist wird das metastasenartige Muster im Rahmen einer klinischen Routineuntersuchung oder im Rahmen der Abklärung anderer Beschwerden gefunden ( Abb. 11A, B). Neben dem metastasenartigen Muster stellt das hämangiomartige Muster die differenzialdiagnostisch schwierigste Form dar ( 

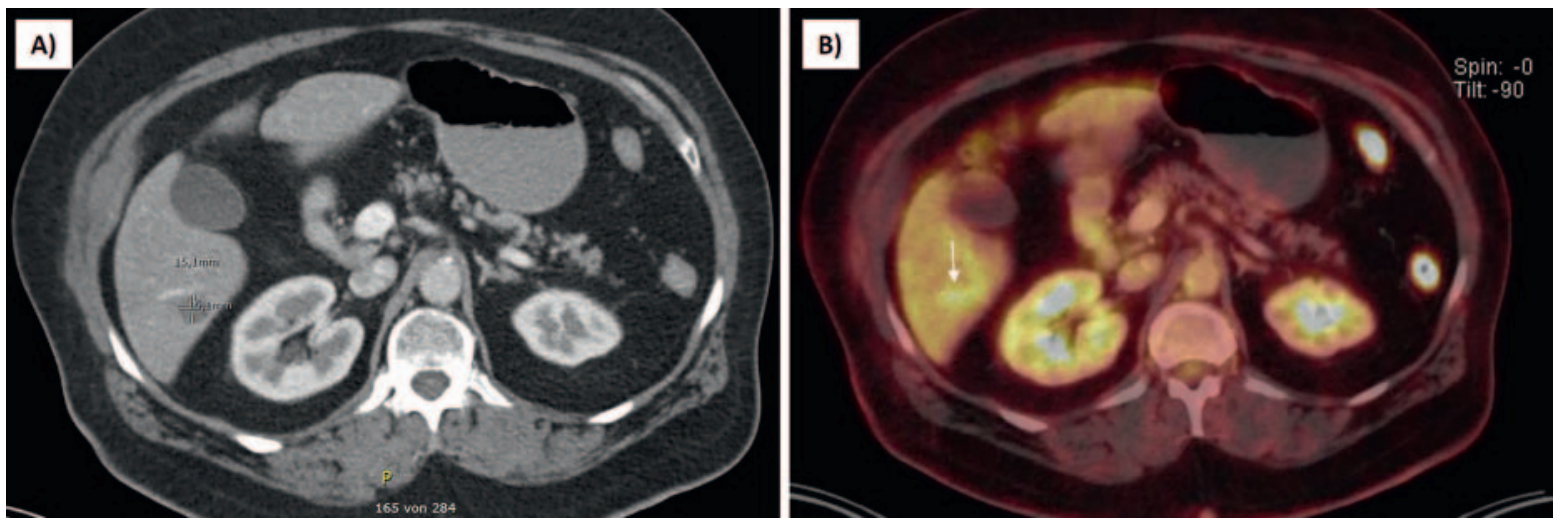

- Fig. 10 A CT for suspected alveolar echinococcosis with corresponding metastatic pattern. B Positron emission computed tomography (PET CT) in suspected alveolar echinococcosis with mildly increased metabolic activity.

- Abb.10 A CT bei Verdacht auf Alveolärer Echinokokkose mit entsprechendem metastasenartigen Muster. B Positronen-Emissions-Computer-Tomographie (PET-CT) bei Verdacht auf Alveolärer Echinokokkose mit gering vermehrter Stoffwechselaktivität.
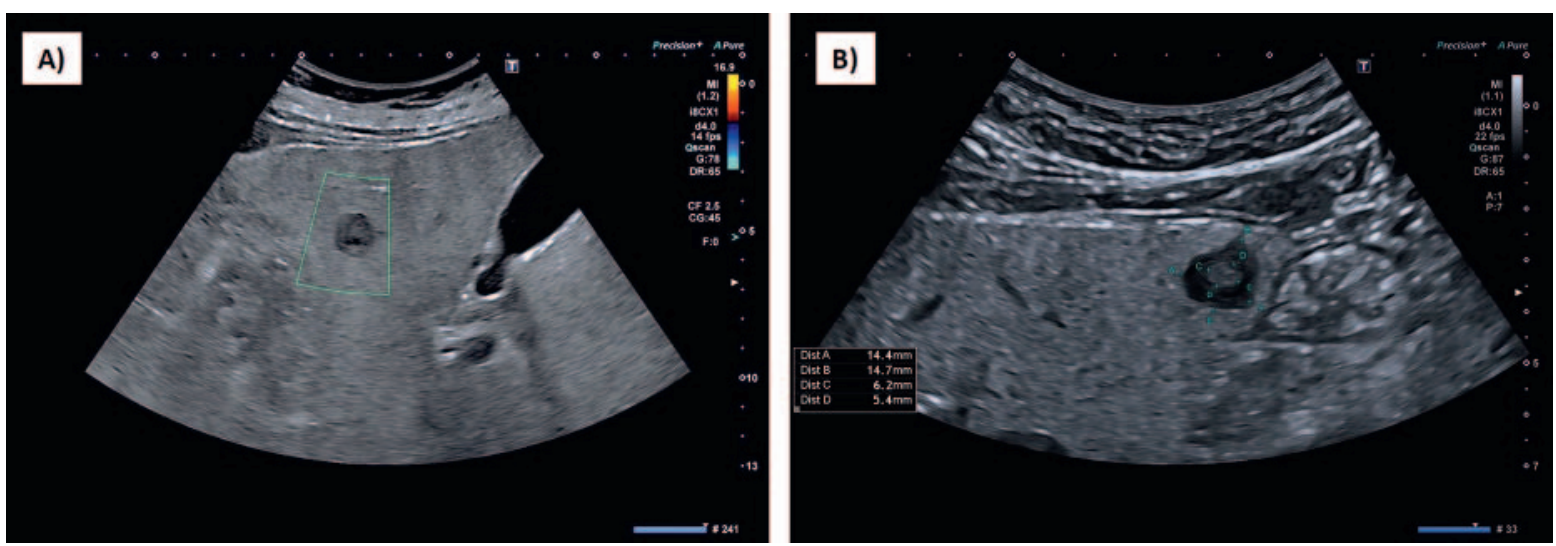

Fig. 11 A, B Examples of two typical metastatic patterns, which were discovered as incidental findings during a routine examination.

Abb. 11 A, B Beispiele von 2 typischen metastasenartigen Mustern, welche im Rahmen einer Routineuntersuchung als Zufallsbefunde entdeckt wurden.

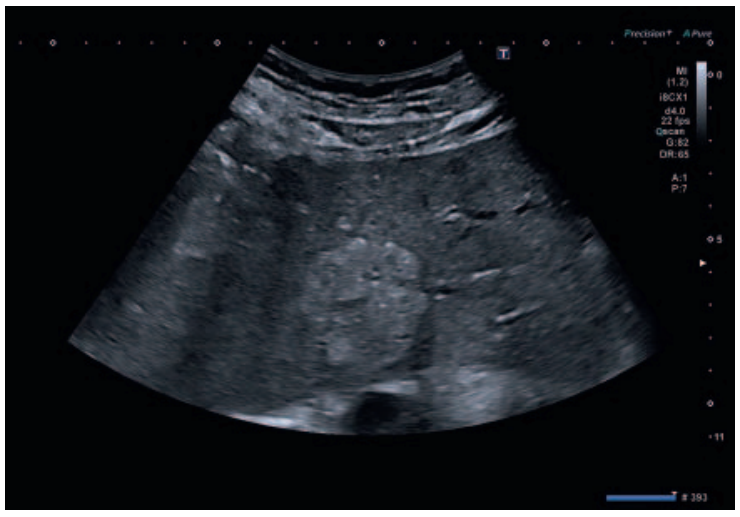

- Fig. 12 Typical image of a hemangioma-like pattern in alveolar echinococcosis.

- Abb. 12 Typisches Bild eines hämangiomartigen Musters bei Alveolärer Echinokokkose. should be taken at $40-50 \mathrm{mg} / \mathrm{kgKG} / \mathrm{d}$ divided into three doses [4].

\section{Canine Tapeworm Disease (Echinococcus multilocularis)}

Unlike fox tapeworm disease (alveolar echinococcosis, $\mathrm{AE}$ ), dog tapeworm disease (cystic echinococcosis, CE) occurs worldwide. However, there are regions with higher infestation rates. In Europe, the focus is on Southern and Eastern Europe and the Balkans ( $\vee$ Fig. 16) [21]. The highest incidence rate in Europe was observed in Sardinia, with more than 8 cases per 100000 population in 2001-2005, but Russia and Turkey also have high infection rates [4]. In Germany, cystic echinococcosis is now classified as a non-autochthonous disease. 

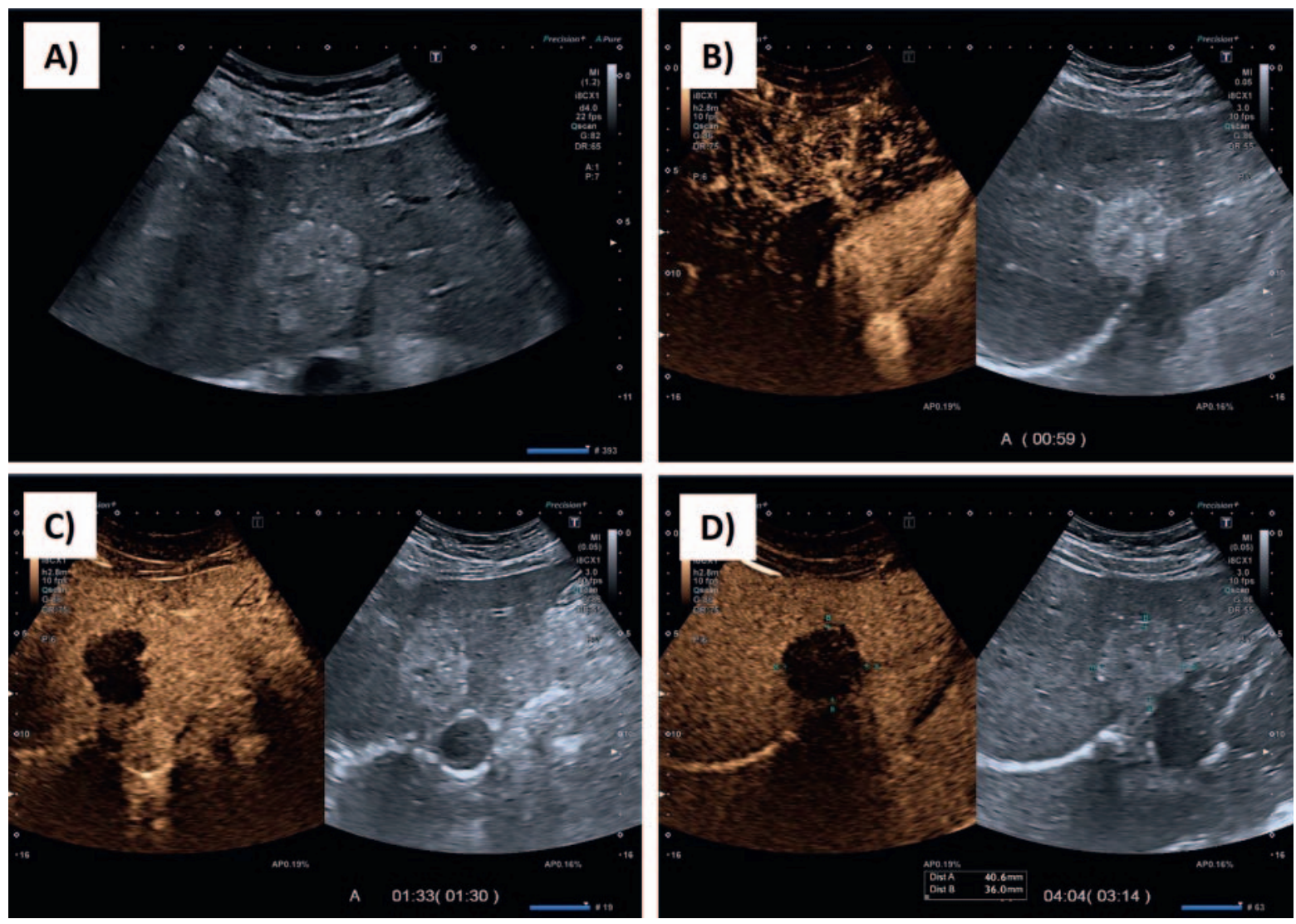

- Fig. 13 Typical image after CEUS of a hemangioma-like pattern in alveolar echinococcosis. A Hemangioma-like pattern on Bscan; B-D The mass shows arterial non-nodular rim enhancement and does absorb contrast centrally during portal and late phases.

- Abb.13 Typisches Muster nach CEUS bei hämangiomartigem Muster bei Alveolärer Echinokokkose. A Hämangiomartiges Muster im B-Bild. B-D Die Raumforderung zeigt arteriell ein nichtknolliges Rim-Enhancement und nimmt während der Portal- und Spätphase zentral kein Kontrastmittel auf.

Die Unterscheidung zwischen einem echten Hämangiom und einem hämangiomartigen Muster bei AE gelingt auch hier nur mithilfe der kontrastverstärkten Sonografie ( Abb. 13A). Das hämangiomartige Muster bei alveolärer Echinokokkose kann ein früharterielles Rim-Enhancement aufweisen. Das typische Kontrastmittelverhalten von Hämangiomen sind eine arterielle periphere noduläre Kontrastverstärkung und eine zentripetale Kontrastmittelanflutung mit komplettem oder inkomplettem Irisblendenphänomen sowie die hyperechogene Darstellung in der Spätphase gegenüber dem echoärmeren Leberparenchym [20] ( Abb. 13B-D). Diese bei „echten Hämangiomen" nachweisbaren Phänomene finden sich beim hämangiomartigen Muster der AE nicht ( $>$ Abb. 14A-D).

\section{Merke}

Mithilfe der kontrastmittelverstärkten Sonografie kann zwischen „echten“ Hämangiomen und dem hämangiomartigen Muster bei alveolärer Echinokokkose differenziert werden. Das typische knollenartige RandEnhancement und ein nachfolgendes komplettes oder inkomplettes Irisblendenphänomen finden sich beim hämangiomartigen Muster der Alveolären Echinokok- kose nicht. In der arteriellen Phase findet sich stattdessen ein Rim-Enhancement. Ansonsten verbleibt die Raumforderung über die gesamte KM-Phase echofrei.

Das sogenannte Verknöcherungsmuster konnte in ca. $13 \%$ der im Nationalen Fuchsbandwurmregister Deutschland erfassten Fälle nachgewiesen werden ( $\triangleright$ Abb. 15A). Es ist davon auszugehen, dass es sich hierbei um eine verkapselte und nicht mehr infektiöse Verkalkungsstruktur handelt. Die bisherigen Ergebnisse der wenigen vorliegenden PET-CT-Untersuchungen konnten bei dieser Präsentationsform keine Aktivität nachweisen [15]. Differenzialdiagnostisch kommt eine Hepatolithiasis oder eine echoreiche Metastase eines Rektumkarzinoms infrage ( $\triangleright$ Abb. 15B, C). Die geschilderten Fälle zeigen die erheblichen Unterschiede in den Präsentationsformen der AE. Stojkovic et al. konnten in einer eindrucksvollen Fallserie die Problematik der Über- und Untertherapie der AE zeigen [3]. Grundsätzlich sollte eine histologische Abklärung bei unklarem sonografischem Befund angestrebt werden. Bei der Abklärung des hämangiomartigen Musters sollte hier vorher zum sicheren Ausschluss eines „echten Hämangioms“ eine kontrastverstärkte Sonografie, 

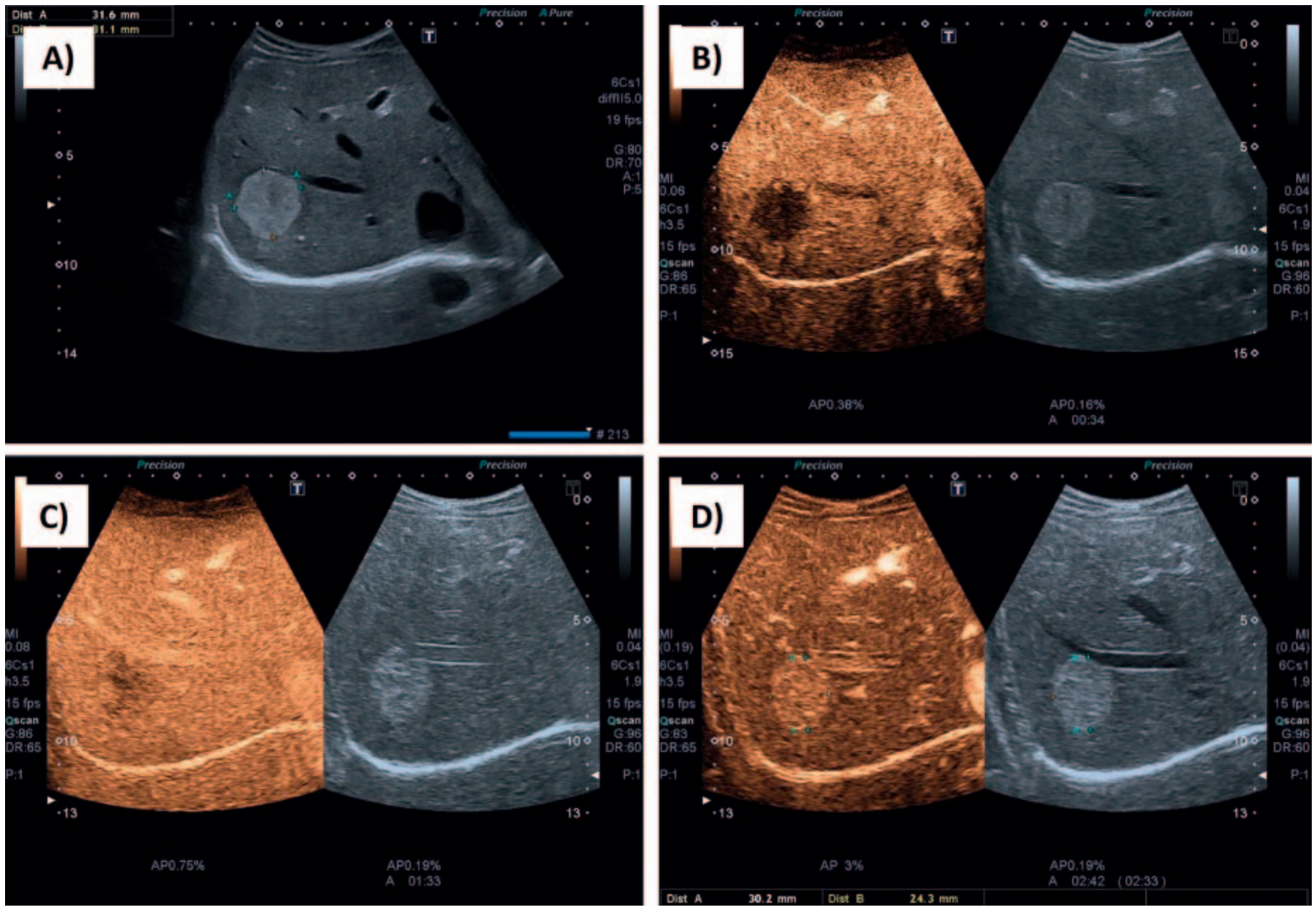

- Fig. 14 A True hemangioma in B-scan; C-D Typical contrast behavior of a true hemangioma with complete iris diaphragm phenomenon.

- Abb.14 A Echtes Hämangiom im B-Bild C-D Typisches Kontrastmittelverhalten eines echten Hämangioms mit komplettem Irisblenden-Phänomen.
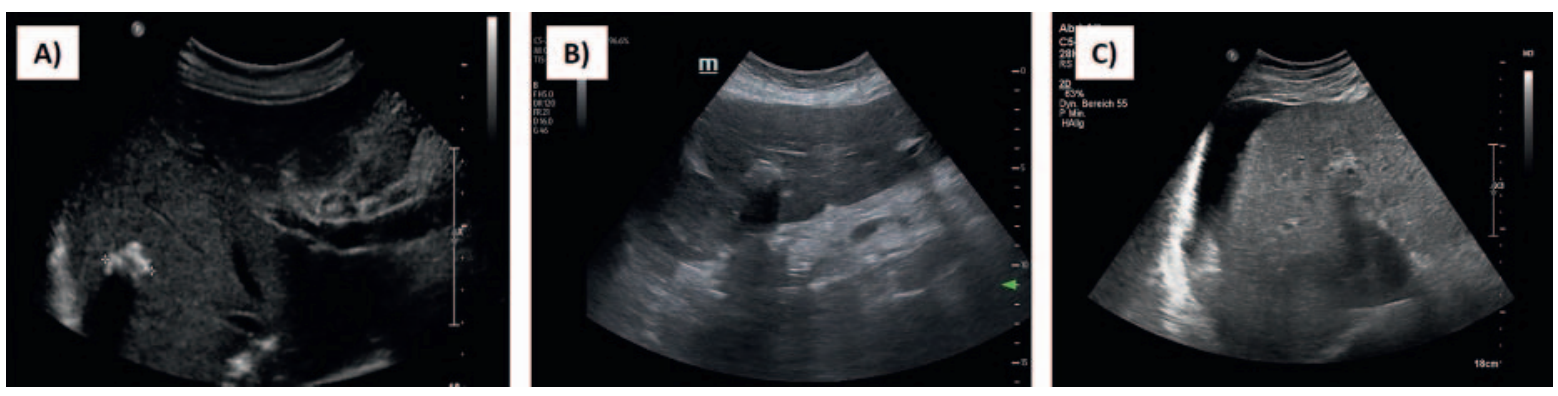

- Fig. 15 A Typical finding of a so-called ossification pattern in alveolar echinococcosis; B Hepatolithiasis; C Hyperechoic metastasis in rectal cancer.

- Abb.15 A Typischer Befund eines sogenannten Verknöcherungsmusters bei Alveolärer Echinokokkose. B Hepatolithiasis.

C Echoreiche Metastase bei Rektumkarzinom.

Infection with the parasite E. granulosus is fecal-oral. Many dogs and other canines are carriers of the parasite E. granulosus. Often, cattle, sheep, horses and other ungulates represent natural intermediate hosts in the development cycle ( $\triangleright$ Fig. 17). After oral ingestion of eggs of $E$. granulosus, the oncospheres (larvae) develop in the small intestine and, after perforation and penetration of the intestinal wall, migrate to the target organs via the blood and lymphatic pathways. In about $70 \%$ of cases, the oncospheres enter the liver, in $20 \%$ of cases, the lungs, and other organs in approx. $10 \%$ of occurrences [21]. In the target organs, the oncospheres sprout into metacestodes and lead to cystic masses. Compared to the fox tapeworm, behavior of these cysts is generally benign [21]. The development cycle is completed when the primary host, such as dogs, ingest the offal of infected animals. 


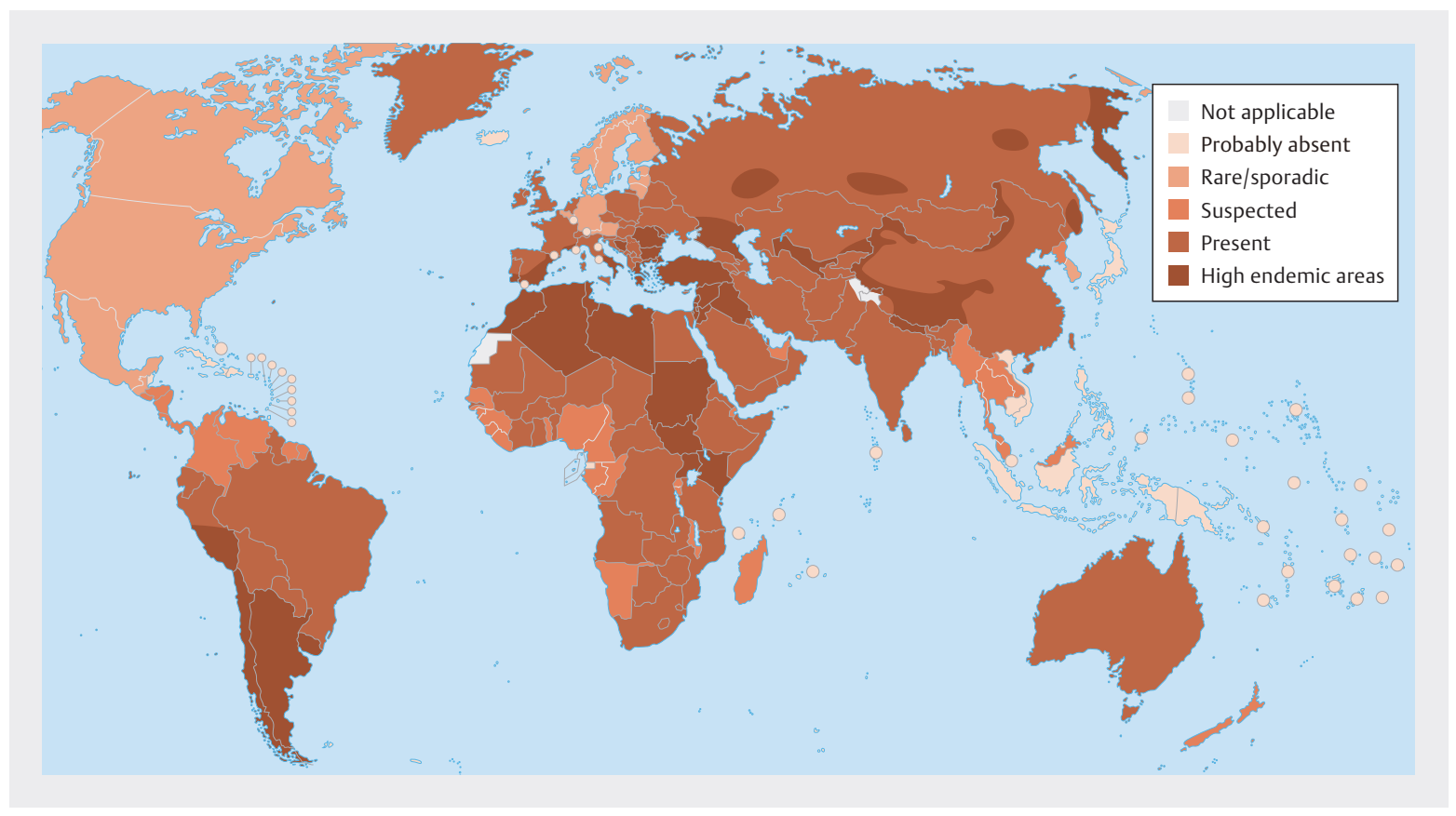

- Fig. 16 Distribution of Echinococcus granulosus and cystic echinococcosis worldwide, 2009 according to the World Health Organization (WHO). Source: https://www.who.int/images/default-source/maps/global_echinococcosis_2009.png? sfvrsn==7a92a53f_o.

- Abb. 16 Verteilung des Echinococcus granulosus und der Zystischen Echinokokkose weltweit, 2009 entsprechend der Weltgesundheitsorganisation (WHO). Source: https://www.who.int/images/default-source/maps/global_echinococcosis_2009.png? sfvrsn==7a92a53f_o.

gegebenenfalls eine weitere Schnittbildgebung mittels Magnet-Resonanz-Tomografie (MRT) erfolgen. Die Einschaltung eines Referenzpathologen bei unklarem histologischem Befund ist zu empfehlen ( $\mathbf{A b b . 9}$ ).

Bei der AE besteht angesichts des infiltrativen Wachstums immer eine Therapieindikation. Als Therapieoptionen stehen die medikamentöse und die chirurgische Therapie zur Verfügung. Etwa ein Drittel der Patienten wird in einem primär lokal operablen Stadium diagnostiziert. Nur durch die operative Resektion der betroffenen Leberanteile mit einem 1-2 cm breiten Sicherheitsabstand besteht eine Chance auf Heilung [4]. Eine medikamentöse Benzimidazol-Therapie ist bei allen Patienten indiziert und mitunter lebenslang erforderlich. Albendazol (ABZ) wird in einer Dosis von $10-15 \mathrm{mg} / \mathrm{kgKG} / \mathrm{d}$ in 2 geteilten Dosen gegeben und ist mit einer fettreichen Mahlzeit einzunehmen. Das einzig verfügbare Alternativpräparat ist Mebendazol, das mit $40-50 \mathrm{mg} / \mathrm{kgKG} / \mathrm{d}$, verteilt auf 3 Dosen einzunehmen ist [4].

\section{Hundebandwurm \\ (Echinococcus granulosus)}

Im Gegensatz zur Fuchsbandwurm-Erkrankung (Alveolären Echinokokkose, AE) kommt die Hundebandwurm-Erkrankung (Zystische Echinokokkose, CE) weltweit vor. Es werden jedoch auch hierbei Regionen mit höheren Durchseuchungsraten beobachtet. In Europa stehen Süd- und Osteuropa sowie der Balkan im Blickpunkt des Geschehens ( Abb. 16) [21]. Die höchste Inzidenzrate in Europa wurde mit über 8 Fällen je 100000 Einwohner im Zeitraum 2001-2005 in Sardinien beobachtet, aber auch Russland und die Türkei haben hohe Infektionsraten zu verzeichnen [4]. Die CE wird in Deutschland mittlerweile als eine nicht autochtone Erkrankung eingestuft.

Eine Infektion mit dem Parasiten E. granulosus erfolgt fäkal-oral. Viele Hunde und andere hundeartige Tiere sind Träger des Parasiten E. granulosus. Häufig stellen Rinder, Schafe, Pferde und andere Huftiere die natürlichen Zwischenwirte im Entwicklungszyklus dar ( $\triangleright$ Abb. 17). Nach oraler Aufnahme von Eiern des E. granulosus entwickeln sich die Onkosphären (Larvenvorstufen) im Dünndarm und wandern nach Perforation und Penetration der Darmwand über den Blut- und Lymphweg zu den Zielorganen. In ca. 70 \% der Fälle gelangen die Onkosphären in die Leber, in $20 \%$ der Fälle in die Lunge und in ca. $10 \%$ in sonstige Organe [21]. In den Zielorganen sprossen die Onkosphären zu Metacestoden aus und führen zu zystischen Raumforderungen. Im Vergleich zum Fuchsbandwurm verhalten sich diese Zysten eher benigne [21]. Der Entwicklungszyklus wird abgeschlossen, wenn der Hauptwirt, wie beispielsweise Hunde, die Schlachtabfälle 


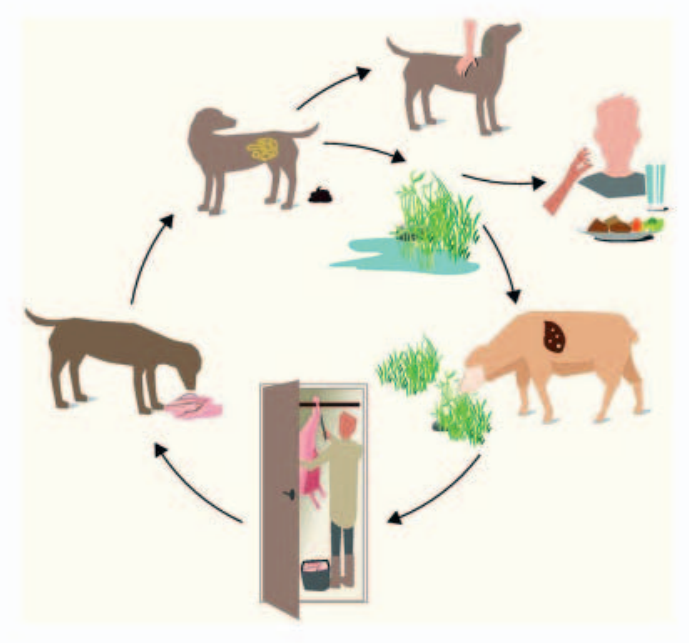

- Fig. 17 Life and developmental cycle of Echinococcus granulosus [4].

- Abb.17 Lebens- und Entwicklungszyklus des Echinococcus granulosus [4].

As in the fox tapeworm cycle, humans are an accidental intermediate host ( $\vee$ Fig. 17).

\section{Cystic Echinococcosis (Canine Tape- worm Disease)}

In Germany, CE is predominantly an imported disease. The majority of patients come from Southeastern Europe, areas of the former Soviet Union or Africa. Conversely, this means that CE should not be initially considered in a native patient with cystic liver lesions [22]. Data from our specialty outpatient clinic show the countries of origin of patients with cystic echinococcosis ( $\mathbf{F i g}$. 18). Almost all of the few patients with dog tapeworm disease of the liver who grew up in Germany have a travel history which explains the $C E$ infection.

\section{Note}

Cystic echinococcosis is an imported disease and occurs predominantly in patients with a migrant background. Cystic echinococcosis in patients raised in Germany is a rarity and is usually explained by a travel history. The recording of a careful travel history and especially contact with dogs or other animals is of particular importance.

A sonomorphological classification has been available for CE for many years [23, 24]. The classification of CE published by WHO shows the possible typical sonographic patterns ( $\triangleright$ Fig. 19). Furthermore, the WHO classification of CE allows the assessment of active and non-active stages according to the indication of need for treatment.

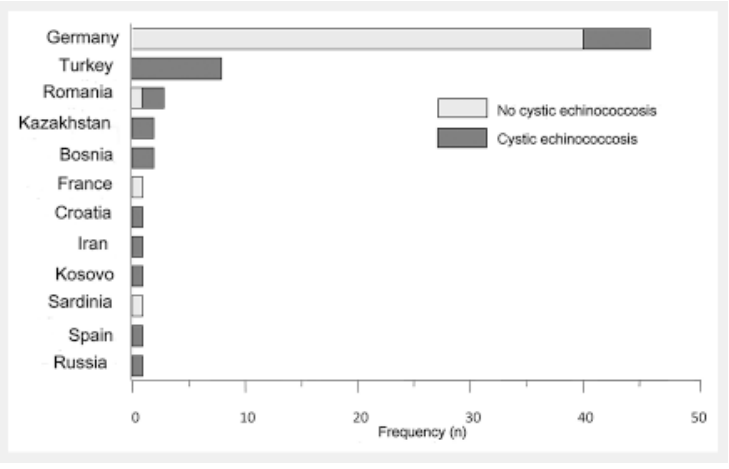

- Fig. 18 Countries of origin of patients with cystic echinococcosis.

- Abb. 18 Herkunftsländer von Patienten mit Zystischer Echinokokkose.

WHO stages CE1 and CE2 are considered active and in need of treatment, stages CE3a and CE3b are considered intermediate, and stages CE4 and CE5 are considered inactive and not requiring treatment. However, stage CE4 should be followed up for a longer period of time when a new diagnosis is made, as stage CE4 can develop into stage CE3b again [4] ( $\triangleright$ Fig. 20).

\section{EXAMPLE CASE 3}

A Syrian patient presents to a physician in private practice for a routine examination. The mildly elevated transaminases ALT $53 \mathrm{U} / \mathrm{I}$ (normal <43U/L), GGT $63 \mathrm{U} / \mathrm{L}$ (normal $<60 \mathrm{U} / \mathrm{L}$ ) result in the performance of a liver ultrasound examination. The examination reveals a large cyst measuring $110 \mathrm{~mm} \times 60 \mathrm{~mm}$ with a hyperechoic wall. Laboratory diagnostics were unremarkable except for discreetly elevated transaminases. No other diseases are known from the previous history. The patient was referred to the university hospital for clarification of the liver cyst. The serological diagnostics performed for suspected cystic echinococcosis results in elevated levels of Echinococcus IgG ElA $153 \mathrm{U} / \mathrm{ml}$ and shows a positive Echi-ELISA result. Based on serology, ultrasound findings, and the patient's origin, therapy with $400 \mathrm{mg}$ albendazole (Eskazole) was initiated. Follow-up ultrasound after two weeks shows a clear change in the sonographic findings ( $\vee$ Fig. 21A, B). Multiple septated cystic lesions form during albendazole therapy. The image shown above in the B-scan and CEUS demonstrates that there is no advantage to using CEUS in the follow-up of cystic echinococcosis. In the further course under albendazole therapy, the endocystic membranes detach from the outer wall (exocyst) ( Fig. 21C). This is also called a "water lily" sign

( $\vee$ Fig. 21C). Further sonographic follow-up of the 


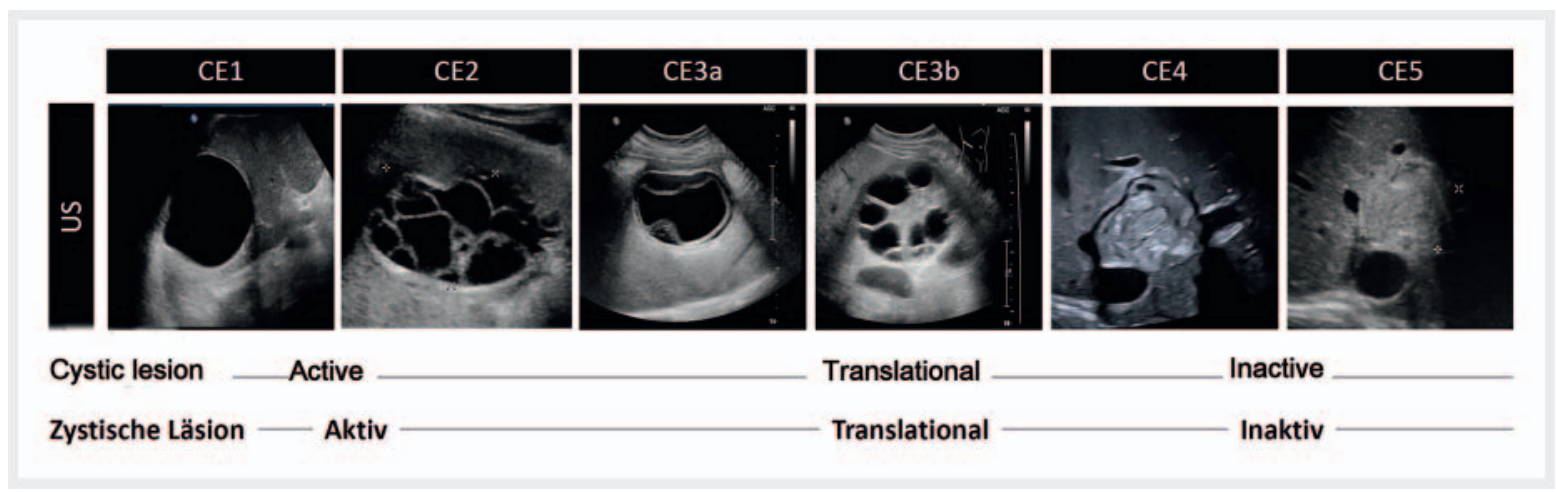

- Fig. 19 WHO-IWGE ultrasound classification of cystic echinococcosis.

- Abb.19 WHO-IWGE Ultraschallklassifikation der Zystischen Echinokokkose.

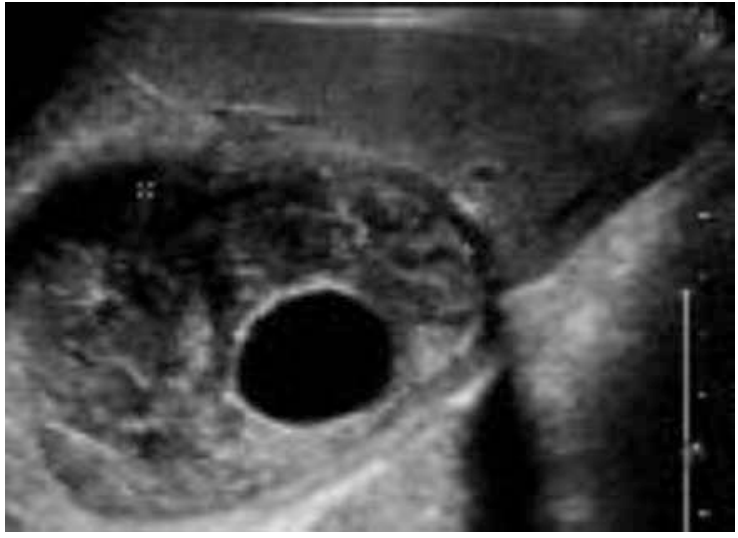

- Fig. 20 WHO CE stage 4. A WHO CE3b stage recurrence is found centrally in this lesion.

- Abb. 20 WHO-CE Stadium 4. Zentral findet sich in dieser Läsion ein WHO-CE3b-Stadium als Rezidiv.

infizierter Tiere aufnehmen. Wie auch im Zyklus des Fuchsbandwurms ist der Mensch ein Fehlzwischenwirt ( Abb. 17).

\section{Zystische Echinokokkose (Hundebandwurm-Erkrankung)}

Die CE stellt in Deutschland überwiegend eine importierte Erkrankung dar. Die Mehrzahl der Patienten stammt aus Südosteuropa, Gebieten der ehemaligen Sowjetunion oder aus Afrika. Das heißt im Umkehrschluss, dass bei einem einheimischen Patienten mit zystischen Leberveränderungen zunächst nicht an die CE gedacht werden sollte [22]. Die Daten aus unserer Spezialambulanz zeigen die Herkunftsländer von Patienten mit zystischer Echinokokkose ( $\mathbf{A b b} \mathbf{1 8}$ ). Die wenigen in Deutschland aufgewachsenen Patienten mit Hundebandwurm-Erkrankung der Leber weisen fast allesamt eine Reiseanamnese auf, welche die Infektion mit CE erklärt.

\begin{abstract}
Merke
Die Zystische Echinokokkose ist eine importierte Erkrankung und kommt überwiegend bei Patienten mit Migrationshintergrund vor. Eine Zystische Echinokokkose bei in Deutschland aufgewachsenen Patienten stellt eine Rarität dar und ist meist durch eine Reiseanamnese erklärt. Die Erhebung einer sorgfältigen Reiseanamnese, insbesondere der stattgehabte Kontakt zu Hunden oder anderen Tieren, ist hier von besonderer Bedeutung.
\end{abstract}

Für die CE steht seit Jahren eine sonomorphologische Klassifikation zur Verfügung [23, 24]. Die von der WHO publizierte Klassifikation der CE zeigt die möglichen typischen sonografischen Muster auf ( $\triangleright$ Abb. 19). Des Weiteren ermöglicht die WHO-Klassifikation der CE die Beurteilung aktiver und nichtaktiver Stadien entsprechend der Notwendigkeit einer Behandlungsindikation.

Die WHO-Stadien CE1 und CE2 gelten als aktiv und behandlungsbedürftig, die Stadien CE3a und CE3b als Intermediärstadien und die Stadien CE4 und CE5 als inaktiv und nicht behandlungsbedürftig. Das Stadium CE4 sollte jedoch bei Neudiagnose für längere Zeit nachbeobachtet werden, da sich in einem Stadium CE4 wieder ein Stadium CE3b ausbilden kann [4] ( Abb. 20).

\section{FALLBEISPIEL 3}

Ein syrischer Patient stellt sich zu einer Routineuntersuchung bei einem niedergelassenen Kollegen vor. Die leicht erhöhten Transaminasen ALT $53 \mathrm{U} / \mathrm{I}$ (Norm $<43 \mathrm{U} / \mathrm{L}$ ), GGT $63 \mathrm{U} / \mathrm{L}$ (Norm < $60 \mathrm{U} / \mathrm{L}$ ) führen zur Durchführung einer Lebersonografie. Hier zeigt sich eine große Zyste mit $110 \mathrm{~mm} \times 60 \mathrm{~mm}$ mit echoreicher Wand. Die Labordiagnostik war bis auf die diskret erhöhten Transaminasen unauffällig. Aus der Vorgeschichte sind keine weiteren Erkrankungen bekannt. Zur Abklärung der Leberzyste wurde der 

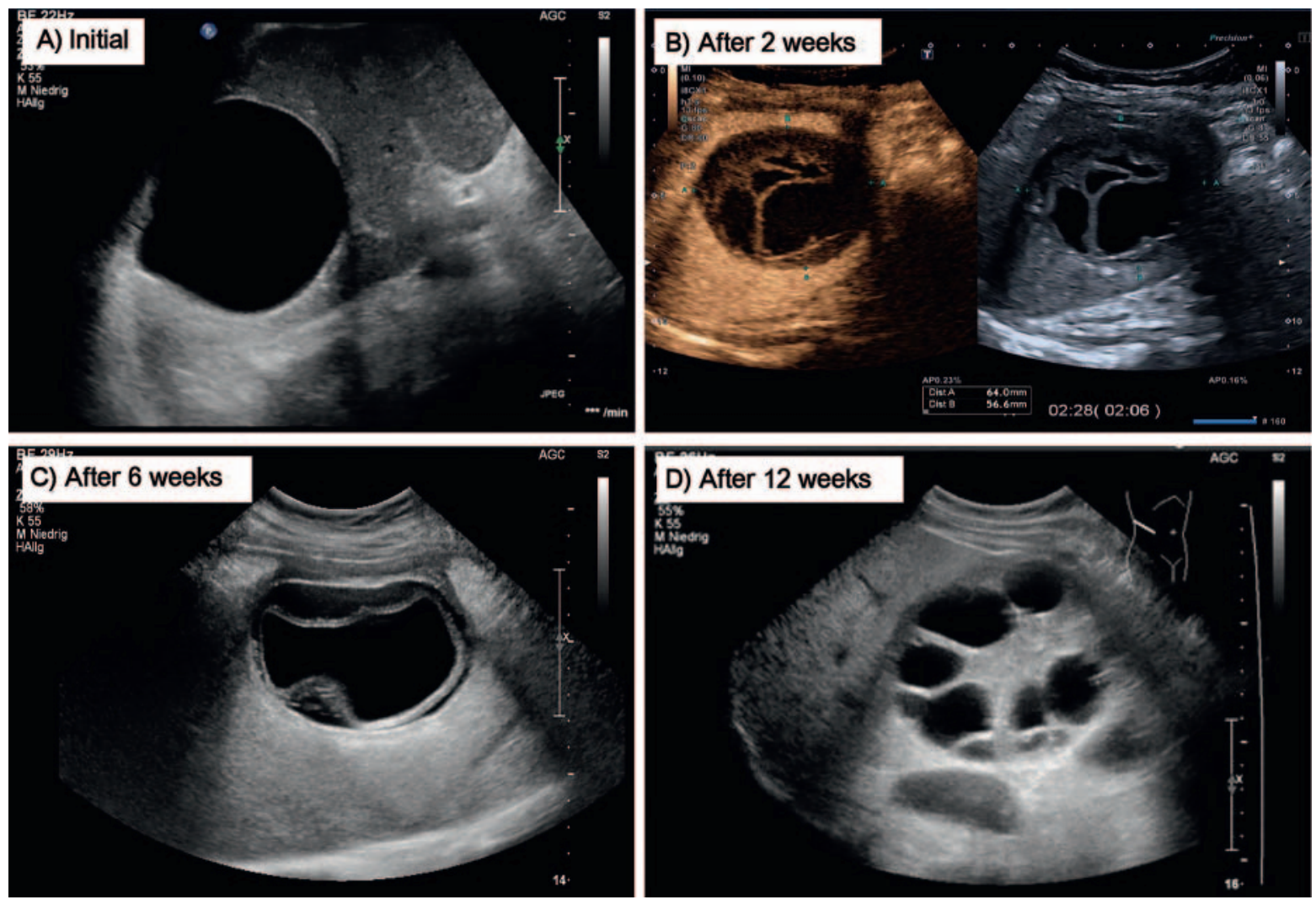

- Fig. 21 A Large cyst in the right hepatic lobe corresponding to WHO CE1 cystic echinococcosis. The cyst meets the criteria of a simple hepatic cyst, but is clearly distinguished from it by the thick hyperechoic wall. B Contrast-enhanced sonography and B-scan ultrasound of the cyst described above shows the formation of multiple septated cystic lesions after 4 weeks of therapy, according to WHO classification CE2. C Typical findings of a WHO classification stage 3a of cystic echinococcosis. D WHO CE stage 3b with a hyperechoic cyst wall, which may be round or oval in appearance, and a honeycomb or radiolucent structure.

- Abb. 21 A Große Zyste im rechten Leberlappen entsprechend einer Zystischen Echinokokkose WHO CE1. Die Zyste weist die Kriterien einer einfachen Leberzyste auf, unterscheidet sich aber deutlich von dieser durch die kräftige echoreiche Wand. B Die kontrastverstärkte Sonografie und B-Bild-Sonographie der oben beschrieben Zyste zeigt nach 4-wöchiger Therapie die Ausbildung mehrerer septierter zystischer Läsionen, entsprechend der WHO-Klassifikation WHO CE2. C Typischer Befund eines Stadiums 3a der WHO-Klassifikation der Zystischen Echinokokkose. D Stadium WHO CE 3b mit echoreicher Zystenwand, welche sich rund oder oval darstellen kann, sowie einer honigwabenartigen bzw. radspeichenartigen Struktur.

patient then shows stage $3 \mathrm{~b}$ after 12 weeks, which is considered to be no longer active ( $\triangleright$ Fig. 21 D).

Basically, the treatment options for CE include a watchand-wait strategy, surgical resection and drug therapy, depending on the organ involvement and stage [4]. Small cysts $(<5 \mathrm{~cm}$ in diameter in stage CE1-CE3a) respond particularly well to drug therapy. About $30 \%$ of patients are cured after 3 to 6 months of treatment. However, longer therapy intervals may also be necessary, and in a few patients, permanent therapy may be necessary. Treatment is less effective for large cysts $(>10 \mathrm{~cm}$ diameter).

The following series of images of a progression of CE over seven years shows that the classic sonographic progression of WHO stages CE2 to CE4 may deviate from the usual patterns. Accordingly, treated stages without previous findings are often very difficult to interpret ( Fig. 22).

The cases presented show that the higher WHO stages CE4 and CE5 cannot be diagnosed exclusively by ultrasound without previous findings. Because of the discontinued activity of stages 4 and 5, ultrasound-guided puncture for clarification of the mass is not a contraindication. The greatest challenge is to differentiate WHO stage CE1 from a simple liver cyst ( $\triangleright$ Fig. 23A, B). In addition to the anamnestic data on the origin of the patient, the number of cysts can be additional important information for possible differentiation.

Frequently, only a singular cyst is detectable in CE. In contrast, simple dysontogenetic liver cysts often occur in greater numbers ( $\triangleright$ Fig. 24) [22]. As a typical sign, a 

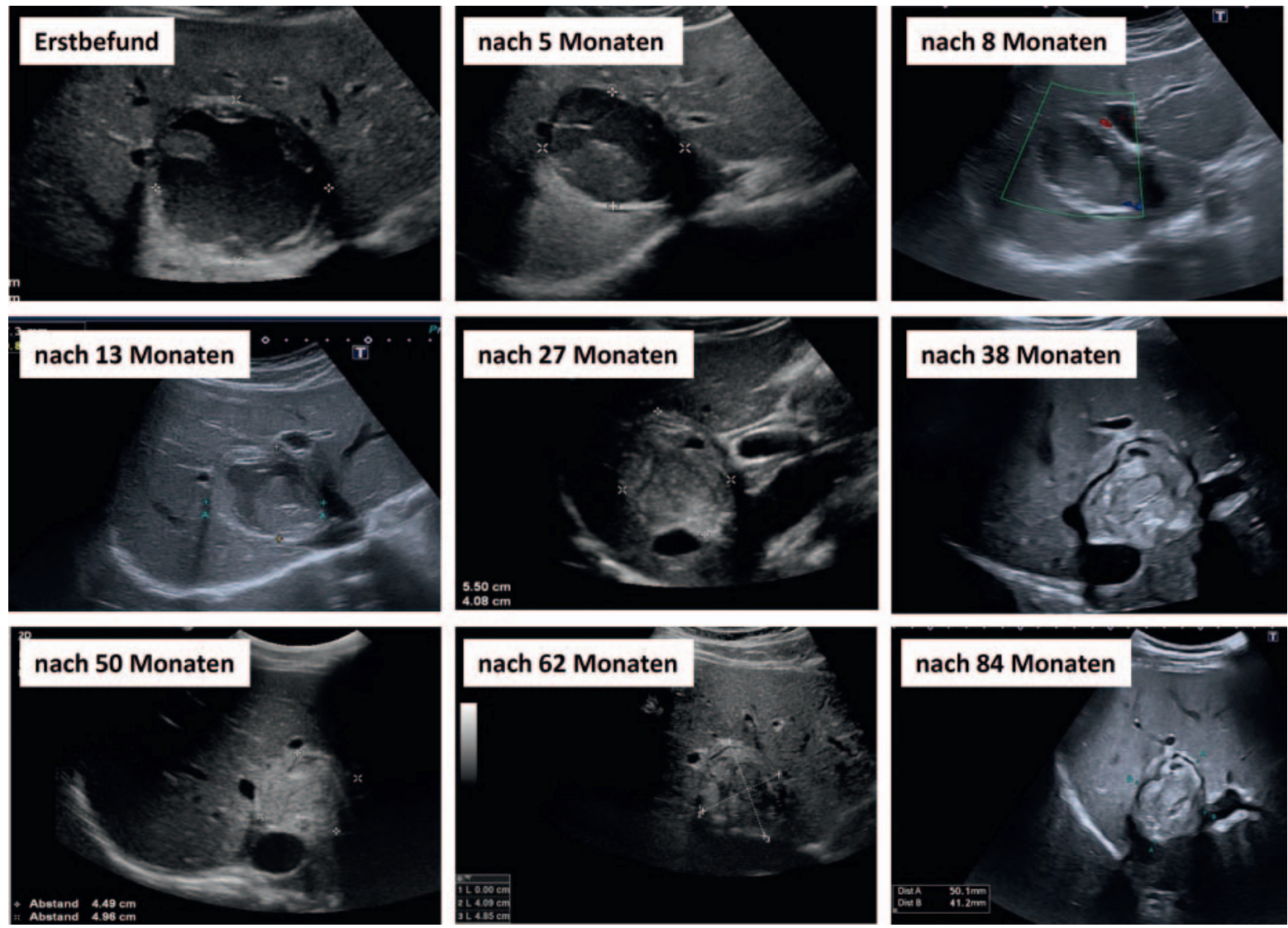

- Fig. 22 This image series shows in progression that the higher stages WHO CE4 and CE5 cannot be diagnosed exclusively by ultrasound without previous findings.

- Abb. 22 Die dargestellte Bildserie zeigt über den zeitlichen Verlauf, dass die höheren Stadien WHO CE4 und WHO CE5 ohne Vorbefund nicht ausschließlich sonografisch diagnostiziert werden können.

Patient an die Universitätsklinik überwiesen. Die durchgeführte serologische Diagnostik bei Verdacht auf Zystische Echinokokkose ergibt erhöhte Werte für Echinococcus IgG ElA $153 \mathrm{U} / \mathrm{ml}$ und zeigt einen positiven Echi-ELISA-Befund. Aufgrund der Serologie, des Ultraschallbefundes und der Herkunft des Patienten wurde eine Therapie mit $400 \mathrm{mg}$ Albendazol (Eskazole) eingeleitet. Die Kontroll-Sonografie nach 2 Wochen zeigt eine deutliche Veränderung des sonografischen Befundes ( $\triangleright$ Abb.21A, B). Unter der Therapie mit Albendazol bilden sich multiple septierte zystische Läsionen. Die oben gezeigte Abbildung im B-Bild und CEUS zeigt, dass die Anwendung von CEUS im Rahmen der Verlaufskontrolle bei zystischer Echinokokkose keine Vorteile bringt. Im weiteren Verlauf unter der Albendazol-Therapie kommt es zur Ablösung der endozystischen Membranen von der Außenwand (Exozyste) ( $\triangleright$ Abb. 21C). Dies wird auch als „Wasserlilien-Zeichen“ bezeichnet ( $\triangleright$ Abb. 21C). Der weitere sonografische Verlauf des Patienten zeigt dann nach 12 Wochen ein Stadium 3b, welches als nicht mehr aktiv gilt ( $\triangleright$ Abb. 21 D).
Grundsätzlich stehen als Therapieoptionen bei CE je nach Organbefall und Stadium eine Watch-and-Wait-Strategie, eine chirurgische Resektion und eine medikamentöse Therapie zur Verfügung [4]. Besonders gut sprechen kleine Zysten ( $<5 \mathrm{~cm}$ Durchmesser im Stadium CE1-CE3a) auf eine medikamentöse Therapie an. Nach einer 3- bis 6-monatigen Therapie sind ca. 30 \% der Patienten geheilt. Längere Therapieintervalle können jedoch auch notwendig sein. Bei wenigen Patienten ist eine dauerhafte Therapie notwendig. Weniger effektiv ist die Therapie bei groBen Zysten (> $10 \mathrm{~cm}$ Durchmesser).

Die nachfolgende Bildserie eines Verlaufs einer CE über 7 Jahre zeigt, dass die klassischen sonografischen Verlaufsformen der WHO-Stadien CE2 bis CE4 von den klassischen Mustern abweichen können. Entsprechend sind anbehandelte und unbehandelte Stadien ohne Vorbefunde oft sehr schwierig zu interpretieren ( $\triangleright$ Abb. 22).

Die dargestellten Fälle zeigen, dass die höheren WHO-Stadien CE4 und CE5 ohne Vorbefund nicht ausschließlich sonografisch diagnostiziert werden können. Aufgrund der nicht mehr bestehenden Aktivität der Stadien 4 und 5 stellt 
more vigorous and hyperechoic cyst wall can be detected in WHO stage CE1 cystic echinococcosis.

A high-grade image-morphologic suspicion of cystic echinococcosis should also be confirmed by serology. A blood test of the patient by enzyme-linked immunosorbent assay (ELISA) with components of the crude antigen from the cyst fluid has a high sensitivity (between 60$95 \%$ depending on the (E stage), but the specificity is not satisfactory. When purified antigens are used, specificity increases, but overall sensitivity and specificity of serology in CE remain unsatisfactory and up to $25 \%$ of CE patients show negative echinococcal serology [4].

\section{Note}

An echinococcus cyst in WHO stage CE1 differs from a simple hepatic cyst mainly by the clearly hyperechoic cyst wall, which cannot be thus visualized in a simple liver cyst. If multiple cysts can be detected, this finding tends to argue against cystic echinococcosis. Echinococcosis cysts often occur individually and rarely in numbers greater than 4 cysts.

\section{Summary of Key Statements}

Fox tapeworm disease (alveolar echinococcosis, $\mathrm{AE}$ ) is a parasitic disease occurring in temperate climates of the northern hemisphere with an endemic focus in southern Germany, northeastern France, Austria and Switzerland. In $\mathrm{AE}$, the stages of metastatic pattern and hemangioma-like pattern cannot be differentiated from possible metastases and true hemangiomas without contrast-enhanced ultrasound. The metastatic pattern presents one of the greatest challenges to sonography, but is extremely rare. The storm and hail pattern is the most common sonographic manifestation of $\mathrm{AE}$, accounting for approximately $50 \%$ of all cases detected in Germany. The pseudocystic pattern of AE may be difficult to differentiate from liver abscesses or atypical cysts solely by using ultrasound. However, clinical data and laboratory values usually aid in differentiation.

Canine tapeworm disease (cystic echinococcosis, CE) is usually a disease imported from countries in southeastern Europe and Africa. Higher WHO stages of cystic echinococcosis CE4 and CE5 cannot be diagnosed as such based on sonomorphology alone without relevant pre- vious findings. WHO stage CE4 must be monitored with ultrasound on a regular basis after initial diagnosis, as recurrences may form again. Patients presenting with CE or AE should be referred to an appropriate specialty and competence center.

\section{Note}

Canine tapeworm disease (cystic echinococcosis, CE) and fox tapeworm disease (alveolar echinococcosis, AE) are two completely separate diseases with different life and development cycles. CE is mostly a disease imported from southern countries with poor socioeconomic conditions. AE is also endemic in Germany, especially in Baden-Württemberg and Bavaria. Therefore, medical history information regarding the patient's place of residence and travel activity is crucial.

Conflict of Interest

\section{Declaration of financial interests}

Receipt of research funding: no; receipt of payment/financial advantage for providing services as a lecturer: no; paid consultant/internal trainer/salaried employee: no; patent/ business interest/shares (author/partner, spouse, children) in company: no; patent/business interest/shares (author/ partner, spouse, children) in sponsor of this CME article or in company whose interests are affected by the CME article: no. Declaration of non-financial interests

The authors declare that there is no conflict of interest.

\section{Correspondence}

\section{Prof. Wolfgang Kratzer}

Department of Internal Medicine I, University Hospital Ulm Albert-Einstein-Allee 23

$89081 \mathrm{Ulm}$

Germany

Tel.: $+49 / 731 / 50044730$

Fax: $+49 / 731 / 50044620$

wolfgang.kratzer@uniklinik-ulm.de

\section{Acknowledgements}

Wir danken Herrn Prof. Dr. Thomas FE Barth und Leonard Scheiber vom Institut für Pathologie am Universitätsklinikum Ulm für die freundliche Bereitstellung des histologischen Bildes. 

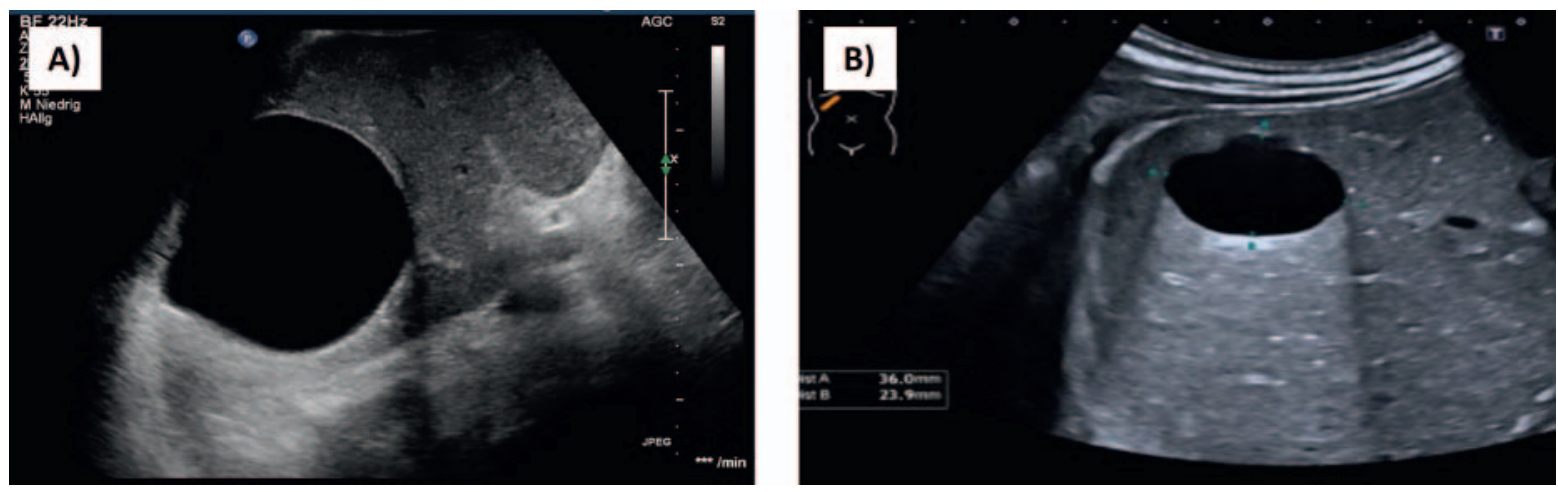

- Fig. 23 A Illustration of cystic echinococcosis WHO stage CE1; B On the right, a simple dysontogenetic cyst.

- Abb.23 A Darstellung einer Zystischen Echinokokkose Stadium WHO CE1. B Rechts eine einfache dysontogenetische Zyste.

eine sonografische Punktion zur Abklärung der Raumforderung keine Kontraindikation dar. Die größte Herausforderung ist die Abgrenzung des Stadiums WHO CE1 gegenüber einer einfachen Leberzyste ( $\vee$ Abb. 23A, B). Neben den anamnestischen Angaben zur Herkunft des Patienten kann hier die Anzahl der Zysten eine weitere wichtige Information zur möglichen Differenzierung sein.

Häufig ist bei der CE nur eine singuläre Zyste nachweisbar. Im Gegensatz dazu treten einfache dysontogenetische Leberzysten häufig zahlreicher auf ( $\triangleright$ Abb. 24) [22]. Als typisches Zeichen kann bei zystischer Echinokokkose im Stadium WHO CE1 eine kräftigere und echoreiche Zystenwand nachgewiesen werden.

Auch ein hochgradiger bildmorphologischer Verdacht auf eine Zystische Echinokokkose sollte mittels Serologie bestätigt werden. Eine Blutuntersuchung des Patienten mittels Enzyme-linked Immunosorbent Assay (ELISA) mit Bestandteilen des Roh-Antigens aus der Zystenflüssigkeit weist eine hohe Sensitivität auf (je nach CE Stadium zwischen 60-95\%), jedoch ist die Spezifität nicht zufriedenstellend. Bei Verwendung gereinigter Antigene steigt die Spezifität, aber insgesamt bleiben Sensitivität und Spezifität der Serologie bei der CE unbefriedigend, und bis zu 25 \% der CE-Patienten zeigen eine negative Echinokokken-Serologie [4].

\section{Merke}

Eine Echinokokkus-Zyste im WHO-Stadium CE1 unterscheidet sich gegenüber einer einfachen Leberzyste vor allem durch die deutlich echoreiche Zystenwand, welche bei einer einfachen Leberzyste so nicht dargestellt werden kann. Können mehrere Zysten nachgewiesen werden, spricht dieser Befund eher gegen eine Zystische Echinokokkose. Echinokokkosen-Zysten treten häufig singulär und selten in einer Zahl von mehr als 4 Zysten auf.

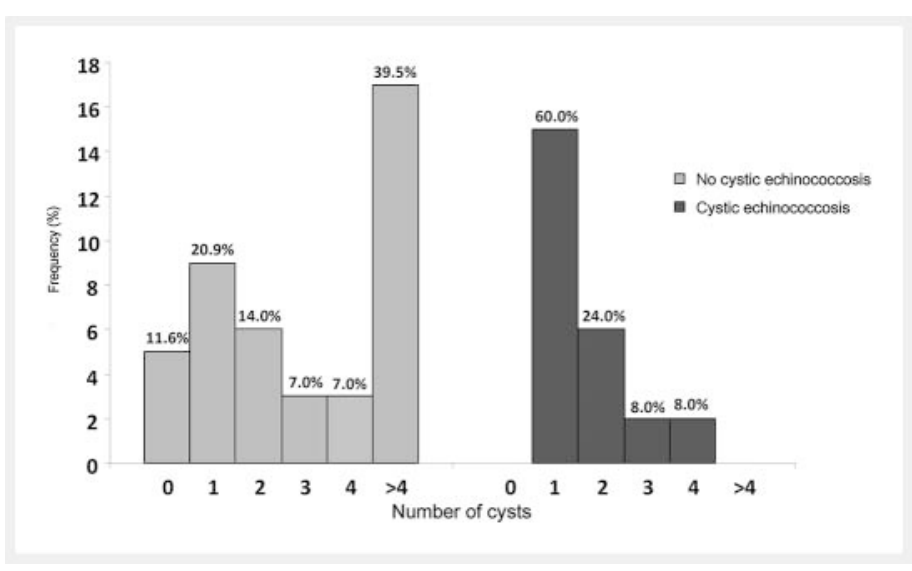

- Fig. 24 Illustration of the number of sonographically-detectable cysts in cystic echinococcosis on the right and simple cysts on the left.

- Abb. 24 Darstellung der Anzahl sonografisch nachweisbarer Zysten bei Zystischer Echinokokkose rechts und einfachen Zysten links.

\section{Zusammenfassung Kernaussagen}

Die Fuchsbandwurm-Erkrankung (Alveoläre Echinokokkose, $\mathrm{AE}$ ) ist eine in gemäßigten Klimazonen der Nordhalbkugel vorkommende parasitäre Erkrankung mit einem endemischen Schwerpunkt in Süddeutschland, Nordostfrankreich, Österreich und der Schweiz. Bei der AE sind die Stadien metastasenartiges Muster und hämangiomartiges Muster ohne die kontrastverstärkte Sonografie nicht von möglichen Metastasen und echten Hämangiomen zu differenzieren. Das metastasenartige Muster stellt eine der größten sonografischen Herausforderungen dar, ist jedoch extrem selten. Das Sturm- und Hagelmuster ist die häufigste sonografische Manifestationsform der AE mit ca. $50 \%$ aller in Deutschland nachgewiesenen Fälle. Das pseudozystische Muster der AE ist ausschließlich sonografisch, und unter Umständen schwer von Leberabszessen oder atypischen Zysten zu differenzieren. Die klinischen Angaben und Laborwerte helfen hier jedoch meist, eine Differenzierung vorzunehmen. 
Die Hundebandwurm-Erkrankung (Zystische Echinokokkose, CE) ist meist eine importierte Erkrankung aus Ländern Südosteuropas und Afrikas. Höhere WHO-Stadien der zystischen Echinokokkose, CE4 und CE5, können alleine an Hand der Sonomorphologie, ohne entsprechende Vorbefunde nicht als solche diagnostiziert werden. Das WHO-Stadium CE4 der CE muss nach Erstdiagnose regelmäßig sonografisch kontrolliert werden, da sich erneut Rezidive bilden können. Die Vorstellung von Patienten mit CE oder AE in einem entsprechenden Spezial- und Kompetenzzentrum ist zu empfehlen.

\section{Merke}

Bei der Hundebandwurm-Erkrankung (Zystischen Echinokokkose, CE) und der Fuchsbandwurm-Erkrankung (Alveolären Echinokokkose, $\mathrm{AE}$ ) handelt es sich um 2 vollständig unterschiedliche Erkrankungen mit unterschiedlichen Lebens- und Entwicklungszyklen. Die CE ist meist eine aus südlichen Ländern mit niedrigem sozioökonomischem Status importierte Erkrankung. Die AE ist auch in Deutschland, insbesondere in BadenWürttemberg und Bayern, endemisch. Die anamnestischen Angaben zum Wohnort und zur Reisetätigkeit des Patienten sind daher von entscheidender Bedeutung.

\section{Interessenkonflikt}

Erklärung zu finanziellen Interessen

Forschungsförderung erhalten: nein; Honorar/geldwerten Vorteil für Referententätigkeit erhalten: nein; Bezahlter Berater/interner Schulungsreferent/Gehaltsempfänger: nein; Patent/Geschäftsanteile/Aktien (Autor/Partner, Ehepartner, Kinder) an Firma (Sponsor der Veranstaltung): nein; Patent/ Geschäftsanteile/Aktien (Autor/Partner, Ehepartner, Kinder) an Firma (Nicht-Sponsor der Veranstaltung): nein.

Erklärung zu nichtfinanziellen Interessen

Die Autorinnen/Autoren geben an, dass kein Interessenkonflikt besteht.

\section{Korrespondenzadresse}

\section{Prof. Wolfgang Kratzer}

Department of Internal Medicine I, University Hospital UIm Albert-Einstein-Allee 23

89081 Ulm

Germany

Tel.: $+49 / 731 / 50044730$

Fax: $+49 / 731 / 50044620$

wolfgang.kratzer@uniklinik-ulm.de

Danksagung

Wir danken Herrn Prof. Dr. Thomas FE Barth und Leonard Scheiber vom Institut für Pathologie am Universitätsklinikum Ulm für die freundliche Bereitstellung des histologischen Bildes.

\section{Literatur}

[1] Kaltenbach TE, Engler P, Kratzer $W$ et al. Prevalence of benign focal liver lesions: ultrasound investigation of 45319 hospital patients. Abdom Radiol (NY) 2016; 41: 25-32

[2] Scharitzer M, Tamandl D, Ba-Ssalamah A. Zufallsbefunde von Leber, Gallensystem, Pankreas und Milz bei asymptomatischen Patienten: Bewertung und Managementempfehlung [Incidental findings of liver, biliary system, pancreas and spleen in asymptomatic patients: Assessment and management recommendations]. Radiologe 2017; 57: 270-278

[3] Stojkovic M, Mickan C, Weber TF et al. Pitfalls in diagnosis and treatment of alveolar echinococcosis: a sentinel case series. BMJ Open Gastroenterol 2015; 2: e000036

[4] Henne-Bruns D, Barth TFE, Gräter T et al. Echinokokkosen der Leber. Allgemein- und Viszeralchirurgie up2date 2016; 10: 369-394

[5] Ammann RW, Eckert J. Cestodes. Echinococcus. Gastroenterol Clin North Am 1996; 25: 655-689

[6] Schmidberger ], Kratzer W, Stark K et al. Alveolar echinococcosis in Germany, 1992-2016. An update based on the newly established national AE database. Infection 2018; 46: 197206

[7] Baumann S, Shi R, Liu W et al. Worldwide literature on epidemiology of human alveolar echinococcosis: a systematic review of research published in the twenty-first century. Infection 2019; 47: 703-727

[8] Pawlowski ZS, Vuitton DA, Ammann RW et al. WHO/OIE Manual on echinococcosis in humans and animals: a public health problem of global concern. World Organisation for Animal Health and WHO 2001: 1-286

[9] Eckert ], Deplazes P. Biological, epidemiological, and clinical aspects of echinococcosis, a zoonosis of increasing concern. Clin Microbiol Rev 2004; 17: 107-135

[10] Romig T, Thoma D, Weible AK. Echinococcus multilocularis-a zoonosis of anthropogenic environments? J Helminthol 2006; 80: 207-212

[11] Stojkovic M, Hoffmann H, Mehrabi A et al. Diagnose und Therapie der Echinokokkosen. Dtsch Med Wochenschr 2017; 142: $1111-1116$

[12] Graeter T, Ehing F, Oeztuerk S et al. Hepatobiliary complications of alveolar echinococcosis: A long-term follow-up study. World J Gastroenterol 2015; 21: 4925-4932

[13] Sezgin O, Altintaş E, Saritaş U et al. Hepatic alveolar echinococcosis: clinical and radiologic features and endoscopic management. J Clin Gastroenterol 2005; 39: 160-167

[14] Kodama Y, Fujita N, Shimizu T et al. Alveolar echinococcosis: MR findings in the liver. Radiology 2003; 228: 172-177

[15] Azizi A, Blagosklonov O, Lounis A et al. Alveolar echinococcosis: correlation between hepatic MRI findings and FDG-PET/CT metabolic activity. Abdom Imaging 2015; 40: 56-63

[16] Didier D, Weiler S, Rohmer P et al. Hepatic alveolar echinococcosis: correlative US and CT study. Radiology 1985; 154 : $179-186$

[17] Kratzer W, Gruener B, Kaltenbach TE et al. Proposal of an ultrasonographic classification for hepatic alveolar echinococcosis: Echinococcosis multilocularis Ulm classification-ultrasound. World J Gastroenterol 2015; 21: 12392-12402

[18] Kratzer W, Schmidberger J, Hillenbrand A et al. Alveoläre Echinokokkose: Eine Herausforderung für Diagnostik, Therapie und Klinisches Management. Epid Bull 2019; 41: 423-430 
[19] Brehm K. Die Echinokokkose - Eine Übersicht und neue Erkenntnisse in der Diagnostik, Therapie und Parasitenbiologie. Epid Bull 2017; 15: 127-132

[20] Dietrich CF, Tana C, Caraiani C et al. Contrast enhanced ultrasound (CEUS) imaging of solid benign focal liver lesions. Expert Rev Gastroenterol Hepatol 2018; 12: 479-489

[21] Mandal S, Mandal MD. Human cystic echinococcosis: epidemiologic, zoonotic, clinical, diagnostic and therapeutic aspects. Asian Pac J Trop Med 2012; 5: 253-260
[22] Wuestenberg J, Gruener B, Oeztuerk S et al. Diagnostics in cystic echinococcosis: serology versus ultrasonography. Turk J Gastroenterol 2014; 25: 398-404

[23] Brunetti E, Kern P, Vuitton DA. Writing Panel for the WHOIWGE. Expert consensus for the diagnosis and treatment of cystic and alveolar echinococcosis in humans. Acta Trop 2010; 114: $1-16$

[24] Brunetti E, Tamarozzi F, Macpherson C et al. Ultrasound and Cystic Echinococcosis. Ultrasound Int Open 2018; 4: E70-E78

\section{CORRECTION 11.03.2022}

Correction: Wolfgang Kratzer, Henriette Weimer, Julian Schmidberger. Echinokokkose: eine Herausforderung der Lebersonographie. Ultraschall in Med 2022; 43: 14-39. DOI 10.1055/a-1694-5552. Published online: 2022-02-24.

In the above-mentioned article, some sentences in the following paragraphs were incorrect. Correct:

\section{English:}

WHO stages CE1 and CE2 are considered active and in need of treatment, stages CE3a and CE3b are considered intermediate, and stages CE4 and CE5 are considered inactive and not requiring treatment. However, stage CE4 should be followed up for a longer period of time when a new diagnosis is made, as stage CE4 can develop into stage CE3b again [4] (Fig. 20).

German:

Die WHO-Stadien CE1 und CE2 gelten als aktiv und behandlungsbedürftig, die Stadien CE3a und CE3b als Intermediärstadien und die Stadien CE4 und CE5 als inaktiv und nicht behandlungsbedürftig. Das Stadium CE4 sollte jedoch bei Neudiagnose für längere Zeit nachbeobachtet werden, da sich in einem Stadium CE4 wieder ein Stadium CE3b ausbilden kann [4] (Abb. 20).

\section{English:}

Fig. 20 WHO CE stage 4. A WHO CE3b stage recurrence is found centrally in this lesion.

\section{German:}

Abb. 20 WHO-CE Stadium 4. Zentral findet sich in dieser Läsion ein WHO-CE3b-Stadium als Rezidiv.

\section{English:}

Frequently, only a singular cyst is detectable in CE. In contrast, simple dysontogenetic liver cysts often occur in greater numbers (Fig. 24) [22]. As a typical sign, a more vigorous and hyperechoic cyst wall can be detected in WHO stage CE1 cystic echinococcosis.

This was corrected in the online version on 11.03.2022. 


\section{CME-Questions}

\section{Question 1}

What is the easiest way to differentiate between cystic (dog tapeworm disease) and alveolar echinococcosis (fox tapeworm disease) based on the patient's history?
A Social history
B Medication history
C Patient care history
D Pain history
E Nutritional history

\section{Question 2}

Which stage of cystic echinococcosis presents the greatest differential diagnostic challenge?
A Stage CE1
B Stage CE2
C Stage CE3
D Stage CE4
E Stage CE5

\section{Question 3}

Are there typical symptoms for alveolar or cystic echinococcosis?
A Diarrhea and exsiccosis
B There are no typical disease symptoms
C Hair and weight loss
D Icterus and elevated liver enzymes
E Upper abdominal pain

\section{Question 4}

Where does alveolar echinococcosis occur most frequently in Germany?
A Berlin and Brandenburg
B Baden-Württemberg and Bavaria
C Hamburg and Bremen
D Hesse and North Rhine-Westphalia
E Lower Saxony and Bremen

\section{Question 5}

Is patient history of origin a helpful tool in the evaluation of ambiguous cystic findings in the liver?
A Origin and travel history are useful
B Origin and travel history are not useful
C No, nutritional history is important
D No, pain history is important
E No, rather biographical and vegetative history

\section{Question 6}

Does the WHO classification of cystic echinococcosis influence related therapy?

A No, classification has no influence on therapy

$B$ Yes, stages CE4 and CE5 require no therapy

C Yes, stages $C E 1$ and $C E 2$ require no therapy

D Yes, stages CE2 and CE3 require no therapy

E Yes, stage CE0 requires therapy

\section{Question 7}

Do the inactive WHO stages of cystic echinococcosis CE4 and CE5 need to be followed up over time?
A No monitoring is necessary
B Stage CE4 must be monitored
C Stage CE5 should be monitored
D Stages CE1-CE do not require monitoring
E All stages require monitoring

\section{Question 8}

What is the best way to distinguish the hemangioma-like pattern of alveolar echinococcosis from a typical hemangioma?
A B-scan ultrasound
B Contrast-enhanced ultrasound
C Elastography
D Serological investigation
E Power Doppler

\section{Question 9}

How is cystic echinococcosis WHO stage CE1 distinguished from a dysontogenetic cyst?
A Pronounced rim enhancement
B Dysontogenetic cysts always appear individually
C Hypoechoic cyst wall
D Hyperechoic cyst wall
E No distinction is possible

\section{Question 10}

Which pattern of AE according to the Echinococcus multilocularis Ulm Classification - Ultrasound (EMUC-US) is most common in Germany and can be considered pathognomonic for the disease?
A Ossification pattern
B Metastatic pattern
C Hemangioma-like pattern
D Pseudocystic pattern
E Storm and hail pattern 


\section{Punkte sammeln auf CME.thieme.de}

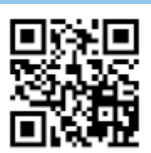

Diese Fortbildungseinheit ist in der Regel 12 Monate online für die Teilnahme verfügbar.

Unter https://eref.thieme.de/cxiy6tp oder über den QR-Code kommen Sie direkt zur Startseite des Wissenstests und zum Artikel. Sie finden dort auch den genauen Einsendeschluss.

Sollten Sie Fragen zur Online-Teilnahme haben, finden Sie unter https://cme.thieme.de/hilfe eine ausführliche Anleitung.

Wir wünschen viel Erfolg beim Beantworten der Fragen!

VNR 2760512022161725835

\section{Frage 1}

Wie kann anamnestisch am einfachsten zwischen einer Zystischen (Hundebandwurm-Erkrankung) und Alveolären Echinokokkose (Fuchsbandwurm-Erkrankung) unterschieden werden?
A Sozialanamnese
B Medikamentenanamnese
C Pflegeanamnese
D Schmerzanamnese
E Ernährungsanamnese

\section{Frage 2}

Welches Stadium der Zystischen Echinokokkose stellt die größte differenzialdiagnostische Herausforderung dar?
A Stadium CE1
B Stadium CE2
C Stadium CE3
D Stadium CE4
E Stadium CE5

\section{Frage 3}

Gibt es typische Symptome für eine Alveoläre- oder Zystische Echinokokkose?
A Diarrhö und Exsikkose
B Es gibt keine typischen Krankheitssymptome
C Haarausfall und Gewichtsverlust
D Ikterus und erhöhte Leberwerte
E Oberbauchschmerzen

\section{Frage 4}

Wo kommt die Alveoläre Echinokokkose in Deutschland am häufigsten vor?
A Berlin und Brandenburg
B Baden-Württemberg und Bayern
C Hamburg und Bremen
D Hessen und Nordrein-Westfalen
E Niedersachsen und Bremen

\section{Frage 5}

Sind anamnestische Angaben zur Herkunft der Patienten ein hilfreiches Instrument bei der Beurteilung unklarer zystischer Befunde in der Leber?
A Anamnestische Angaben zur Herkunft und Reiseanamnese sind hilfreich
B Anamnestische Angaben zur Herkunft sind nicht hilfreich
C Nein, eine wichtige anamnestische Angabe ist das Ernährungs- verhalten
D Nein, eine wichtige anamnestische Angabe ist die Schmerza- namnese
E Nein, aber die biografische und vegetative Anamnese

\section{Frage 6}

Hat die WHO-Klassifikation der Zystischen Echinokokkose Einfluss auf die deren Therapie?
A Nein, die Klassifikation hat keinen Einfluss auf die Therapie
B Ja, Stadium CE4 und CE5 benötigen keine Therapie
C Ja, Stadium CE1 und CE2 benötigen keine Therapie
D Ja, Stadium CE2 und CE3 benötigen keine Therapie
E Ja, Stadium CEO benötigt eine Therapie

\section{Frage 7}

Müssen die inaktiven WHO-Stadien der Zystischen Echinokokkose CE4 und CE5 im Verlauf nachkontrolliert werden?

A Es ist keine Kontrolle erforderlich

B Stadium CE4 muss nachbeobachtet werden

C Stadium CE5 sollte nachbeobachtet werden

D Die Stadien CE1-CE3 müssen nicht nachbeobachtet werden

E Alle Stadien müssen nachbeobachtet werden

- Weitere Fragen auf der folgenden Seite... 


\section{Punkte sammeln auf CME.thieme.de}

\section{Frage 8}

Wie lässt sich das hämangiomartige Muster der Alveolären Echinokokkose am besten von einem typischen Hämangiom unterscheiden?
A B-Bild-Sonografie
B Kontrastverstärkte Sonografie
C Elastografie
D Serologische Untersuchung
E Powerdoppler

\section{Frage 9}

Wie lässt sich zwischen einer Zystischen Echinokokkose WHO Stadium CE1 und einer dysontogenetischen Zyste unterscheiden?
A Ausgeprägtes Rim-Enhancement
B Dysontogenetische Zysten liegen immer singulär vor
C Echoarme Zystenwand
D Echoreiche Zystenwand
E Es ist keine Unterscheidung möglich

\section{Frage 10}

Welches Muster der AE nach der Echinococcus multilocularis Ulm Classification - Ultrasound (EMUC-US) kommt am häufigsten in Deutschland vor und kann als pathognomonisch für die Erkrankung angesehen werden?
A Verknöcherungsmuster
B metastasenartiges Muster
C hämangiomartiges Muster
D pseudozystisches Muster
E Sturm- und Hagelmuster 
Continuing Medical Education (CME) - important note for readers outside Austria, Germany and Switzerland

At present, certification of the Continuing Medical Education features in Ultraschall in der Medizin/European Journal of Ultrasound (UiM/EJU) is officially recognised by the German and Austrian medical associations and by the Swiss Ultrasound Society. Participants residing in other countries may please address their national medical association or their national specialist society for recognition of their CME scores.

Participation is possible via internet under http:// cme.thieme.com. For one Continuing Medical Education unit you will be credited with 3 score points. To be awarded this score, $70 \%$ of the questions must have been answered correctly. The CME unit in the present issue is available online for 12 months for CME participation.

CME participation for this article can be done online under http://cme.thieme.com.

\section{CME-Fortbildung mit Ultraschall in der Medizin}

\section{Für Teilnehmer in Deutschland}

Die Fortbildung in Ultraschall in der Medizin wurde von der Nordrheinischen Akademie für Ärztliche Fortund Weiterbildung für das Fortbildungszertifikat anerkannt, das heißt, die Vergabe der Punkte kann direkt durch die Thieme Verlagsgruppe erfolgen. Die Fortbildung in Ultraschall in der Medizin gehört zur Kategorie „strukturierte interaktive Fortbildung“. Entsprechend einer Absprache der Ärztekammern werden die von der Nordrheinischen Akademie für Ärztliche Fort- und Weiterbildung anerkannten Fortbildungsveranstaltungen auch von den anderen zertifizierenden Ärztekammern anerkannt.

\section{Für Teilnehmer in Österreich}

Die Fortbildungspunkte der Ultraschall in der Medizin werden gemäß der Novellierung der DFP-
Richtlinien vom 23.6.2005 (§26 Abs. 3) auch von den österreichischen Ärztekammern anerkannt.

\section{Für Teilnehmer in der Schweiz}

Die Fortbildungspunkte der Ultraschall in der Medizin werden gemäß der Richtlinien der SGUM im Rahmen der 15 Credits für das Selbststudium anerkannt. Die Kontrolle der Fortbildung durch die SGUM/SSUM erfolgt im Auftrag der FMH (Foederation Medicorum Helveticorum) im Rahmen der Fortbildungsordnung.

\section{Datenschutz}

Ihre Daten werden ausschließlich für die Bearbeitung dieser Fortbildungseinheit verwendet. Es erfolgt keine Speicherung der Ergebnisse über die für die Bearbeitung der Fortbildungseinheit notwendige Zeit hinaus. Die Daten werden nach Versand der Testate anonymisiert. Namens- und Adressangaben dienen nur dem Versand der Testate. Die Angaben zur Person dienen nur statistischen Zwecken und werden von den Adressangaben getrennt and anonymisiert verarbeitet.

\section{Teilnahme}

Jede Ärztin und jeder Arzt soll das Fortbildungszertifikat erlangen können. Deshalb ist die Teilnahme am CME-Programm von Ultraschall in der Medizin nicht an ein Abonnement geknüpft! Die Teilnahme ist im Internet unter http://cme.thieme.de möglich. Im Internet muss man sich registrieren, wobei die Teilnahme an Fortbildungen abonnierter Zeitschriften ohne Zusatzkosten möglich ist. Die Fortbildungseinheit in diesem Heft ist 12 Monate online für eine CME-Teilnahme verfügbar.

\section{Teilnahmebedingungen}

Für eine Fortbildungseinheit erhalten Sie 3 Fortbildungspunkte im Rahmen des Fortbildungszertifikats. Hierfür müssen $70 \%$ der Fragen richtig beantwortet sein.

\section{CME-Fortbildung für Nicht-Abonnenten}

Teilnehmer, die nicht Abonnenten von Ultraschall in der Medizin sind, können für die Internet-Teilnahme dort direkt ein Guthaben einrichten, von dem pro Teilnahme ein Unkostenbeitrag abgebucht wird.

\section{Die CME-Teilnahme für diesen Beitrag ist} online möglich unter http://cme.thieme.de.

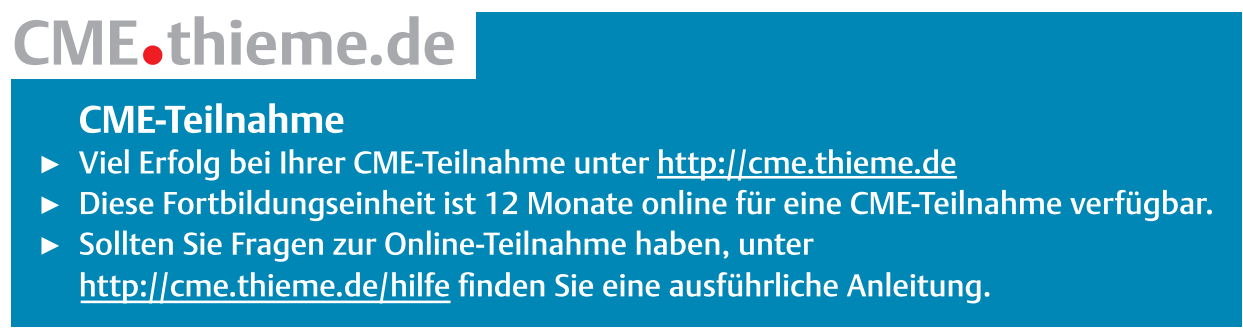

